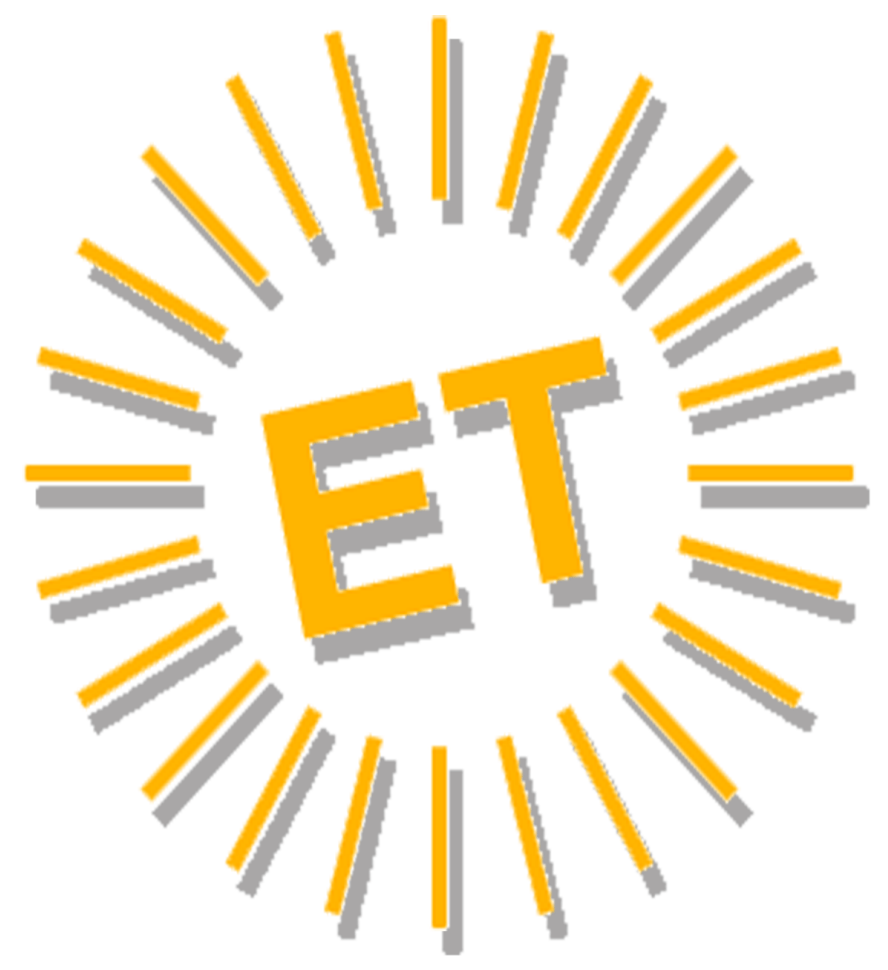




\section{Editorial Team}

\section{Editor in Chief}

Alfonso Vargas-Sánchez, University of Huelva, Spain

\section{Associate Editor}

Mirko Perano, Reald University College, Albania

\section{Books Review Editor}

Brendan Paddison, York St. John University, United Kingdom

\section{Secretariat}

Elena García de Soto, University of Huelva, Spain

Cinta Borrero-Domínguez, University of Seville, Spain

\section{Style reviewer and text editor}

Anestis Fotiadis, Zayed University, United Arab Emirates

\section{Editorial Board}

José Manuel Alcaraz, Murdoch University, Australia Mario Castellanos-Verdugo, University of Seville, Spain José Antonio Fraiz-Brea, University of Vigo, Spain José Manuel Hernández-Mogollón, University of Extremadura, Spain

Tzung-Chen Huan, National Chiayi University, Taiwan, Province of China

Shaul Krakover, Ben Gurion University, Israel Jean Pierre Levy-Mangin, University of Quebec, Canada Tomás López-Guzmán, University of Córdoba, Spain Yasuo Ohe, Chiba University, Japón

María de los Ángeles Plaza-Mejía, University of Huelva, Spain Nuria Porras-Bueno, University of Huelva, Spain João Albino Silva, Algarve University, Portugal

\section{Advisory Board (Spanish Members)}

Juan Manuel Berbel-Pineda, Pablo de Olavide University, Spain César Camisón-Zornoza, Uniersity of Valencia, Spain Enrique Claver-Cortés, University of Alicante, Spain María Teresa Fernández-Alles, University of Cádiz, Spain José Luis Galán-González, University of Seville, Spain Félix Grande-Torraleja, University of Jaén, Spain

Antonio Leal-Millán, University of Seville, Spain Inmaculada Martín-Rojo, University of Málaga, Spain Antonio Manuel Martínez-López, University of Huelva, Spain Francisco José Martínez-López, University of Huelva, Spain Pablo A. Muñoz-Gallego, University of Salamanca, Spain
Francisco Riquel-Ligero, University of Huelva, Spain José Miguel Rodríguez-Antón, Autonomous University of Madrid, Spain

Sandra Sanchez-Cañizares, University of Cordoba, Spain Josep Francesc Valls-Giménez, ESADE, Spain

\section{Advisory Board (Other European Members)}

Tindara Abbate, University of Messina, Italy Paulo Aguas, University of Algarve, Portugal Carlos Costa, Aveiro University, Portugal Dianne Dredge, Aalborg University, Denmark Salvatore Esposito de Falco, University of Rome "La Sapienza", Italy

Sheila Flanagan, Dublín Institute of Technology, Ireland Tania Gorcheva, Tsenov Academy of Economics, Bulgaria Tadeja Jere Jakulin, University of Primorska, Slovenia Metin Kozak, Mugla University, Turkey Álvaro Matias, Lusiada University, Portugal Alfonso Morvillo, National Research Council, Italy Alexandru Nedelea, Stefan cel Mare University of Suceava, Romania Claudio Nigro, University of Foggia, Italy Angelo Presenza, University "G. D'Annunzio" of Chieti-Pescara, Italy

Kanes Rajah, Royal Agricultural University, United Kingdom

\section{Advisory Board (Members from the rest of the world)}

John Allee, American University of Sharjah, United Arab Emirates

Nestor Pedro Braidot, National University of La Plata, Argentina

Roberto Elias Canese, Columbia University, Rector, Paraguay

Luca Casali, Queensland University of Technology, Australia Nimit Chowdhary, Indian Institute of Tourism and Travel Management, India

Steven Chung-chi Wu, National Pingtung University of Science and Technology, Taiwán

Dianne Dredge, Southern Cross University, Australia Daniel Fesenmaier, Temple University, United States

Babu George, Alaska Pacific University, United States Dogan Gursoy, Washington State University, United States Jafar Jafari, University of Wisconsin-Stout, United States Sanggun Lee, Pai Chai University, Korea Republic of Albert Yeh Shangpao, I-SHOU University, Taiwán Pauline Sheldon, University of Hawaii, United States Germán A. Sierra-Anaya, University of Cartagena de Indias, Rector, Colombia Xiaohua Yang, University of San Francisco, United States 


\title{
ACHIEVING SERVICE RECOVERY THROUGH SERVICE INNOVATION IN THE HOTEL INDUSTRY: THE CRITICAL ROLE OF EMPLOYEE EMPOWERMENT
}

\author{
Mukhles M. Al-Ababneh \\ Al-Hussein Bin Talal University (Jordan) \\ mukhles.ababneh@gmail.com \\ Mousa A. Masadeh \\ Al-Hussein Bin Talal University (Jordan) \\ jordantourism@hotmail.com \\ Samer M. Al-Sabi \\ Al-Hussein Bin Talal University (Jordan) \\ alsabi@gmail.com
}

Mohammad B. Al-Badarneh

Yarmouk University (Jordan)

baadarneh@gmail.com

\begin{abstract}
Research in service recovery and service innovation has attracted significant attention in recent years but few studies have focused on achieving service recovery through service innovation. The current study aims to bridge this gap in research - to investigate the effect of service innovation on service recovery. Additional emphasis is also given to


examining whether employee empowerment serves as a mediator between service innovation and service recovery in the hotel industry. A quantitative survey method was applied by using a 60-item questionnaire and data collected from a sample of 381 employees from five-star hotels in Jordan. The findings confirmed the hypotheses, revealing a direct effect of service innovation on employee empowerment which, in turn, had a significant influence on service recovery. Additionally, this study proposed a model of influence of service innovation in service recovery, whereby employee empowerment fully mediates this relationship. The current study contributes to the existing literature on service innovation and service recovery as it identifies the role of service innovation in enhancing service recovery performance in hotels.

KEYWORDS

Service Recovery; Service Innovation; Employee Empowerment; Hotels.

ECONLIT KEYS

L83, M31, O30

\section{INTRODUCTION}

The characteristic of inseparability in provided services and the high degree of contact between service providers and customers increase the likelihood of service failure in the service industry, thus gaining service recovery particular attention from scholars (Petzer \& Steyn, 2006). Employees making mistakes in the service context can lead to service systems breaking down at any time because there is no perfect service system that would not cause problems for customers (Al-Ababneh et al., 2018). Service failure is inevitable in the hospitality industry due to its multitudes of intangible aspects and complex operations (Black \& Kelley, 2009). It occurs when a customer has an unpleasant experience (Bitner, Booms \& Tetreault, 1990) or feels dissatisfied with the service received (Hsieh \& Yeh, 2018), following which some customers raise their complaints to service providers (Ro, 2013). Effective service recovery strategies should be used by service providers during the second service delivery process to confront the failure and recover it, repairing the damage caused to customers (Grönroos, 1988) and addressing customer dissatisfaction to potentially enhance customer relationships (Sajtos, Brodie \& Whittome, 2010) by regaining customer satisfaction more than they would have prior to the service failure (Casidy \& Shin, 2015; 
Hsieh \& Yeh, 2018) and to convert customer dissatisfaction into customer loyalty (Magnini et al., 2007). Accordingly, many hospitality organisations have adopted service recovery into their company policy to address customer dissatisfaction (MeliánGonzález, Bulchand-Gidumal \& Lopez-Valcárcel, 2013).

The process of service recovery is an effective response to service failures - an important method requiring immediate catering to customer problems and engaging in good actions to solve them (Maxham, 2001; Ogbeide et al., 2017). Service recovery refers to the actions that can be taken by a company in response to a case of service failure (Grönroos, 1988), it encompasses the corrective actions (i.e., acknowledgement of the problem, explanation of the problem, apologies and monetary compensation) that are taken by service providers to reduce the damage to customers (Wong, Newton \& Newton, 2016; Cheng et al., 2018). Customer complaints or feedbacks act as sources of ideas in the service recovery process, enhancing the services provided to customers (Schoefer \& Ennew, 2004). Thus, managing service failures minimises the negative impacts of customers' bad experiences by rectifying these issues with care, further encouraging customer loyalty (Cheng et al., 2018). As a result, appropriate service recovery strategies can be implemented by assessing their existing resources to provide the best possible solutions to their customers (Hsieh \& Yeh, 2018).

Hospitality organisations face challenges of a turbulent and unstable environment due to high technology, globalisation, intensified competition, open international markets, rapid changes in the world economy and high pressure to increase profitability in the challenging situation (Daghfous \& Barkhi, 2009; Al-Ababneh, 2014), forcing them to implement service innovation as a way to meet changes in customer needs and survive in the market. Consequently, service innovation in the hospitality industry became a vital technique for business survival, competitiveness, business excellence, growth and success (Ottenbacher, 2007; Orfila-Sintes \& Mattsson, 2009). Service innovation refers to service/product innovation, process innovation and organisational and marketing innovation (OECD \& Eurostat, 2005; Rao, Yang \& Yang, 2018). Furthermore, effective service innovation could bring forth new services/products, techniques, organisational structures and operation methods, which will further enhance service quality and lead to greater customer satisfaction (Rao et al., 2018). 
Innovation seeks new and better solutions to customer, product and business problems (Herbig \& Jacobs, 1996; Mostafa, 2005), it is a necessary requirement for organisational effectiveness (Basadur, Pringle \& Kirkland, 2002). Thus, successful organisations depend on innovation now more than ever (Wong \& Pang, 2003a). Service innovation has positive impacts on service quality, customer preferences and their retention, employee productivity, the organisation's market value and share (Martínez-Ros \& Orfila-Sintes, 2009; Sok \& O’Cass, 2015; Gomezelj, 2016). Hospitality organisations can offer renewed or new products/services by adapting themselves to changes (Gomezelj, 2016). Service innovation in the hospitality industry requires employee involvement and the participation of current and prospective customers (Orfila-Sintes \& Mattsson, 2009). Thus, service organisations can use employee empowerment as a tool for handling customer demands by improving service quality (Cho, Laschinger \& Wong, 2006).

All the previous studies focused on service innovation and its impact on service quality and customer satisfaction, while other studies focused on service recovery and its impact on customer satisfaction. The majority of these studies used empowerment as a mediator for achieving high service quality and customer satisfaction. Even though the concept of empowerment has received much attention in previous research, how empowerment mediates the relationship between service innovation and service recovery remains a relatively unexplored research area. Thus, there is a need to examine the mediating role of empowerment between service innovation and service recovery in five-star hotels in Jordan from the employees' perspective. However, no study has been conducted to investigate the impact of service innovation on service recovery. Accordingly, this study implies that service providers should improve their service recovery through the invention of service innovation in order to enhance customer satisfaction, which can help hospitality organisations build their sustainable competitive advantage to compete against other contenders in highly combative environments.

The importance of this study arose from the importance of service innovation and service recovery in hotels and for customers, improving hotels' service quality and enhancing their competitive advantage, ultimately achieving customer satisfaction. Service innovation could create new processes or improve the current processes to enhance the efficiency of service recovery. In the previous studies, it was found that 
employee empowerment is strongly related to and mediates most relationships with service recovery, proving to play an essential part in the service recovery process. Thus, this study proposed the mediation role of employee empowerment in the relationship between service innovation and service recovery.

To the best of the authors' knowledge, this study is considered the first which may contribute to the field of study by implementing service innovation as a new approach that enhances the process of service recovery by empowering employees in the hotel industry. The purpose of this study is to explore the relationship between service innovation and service recovery, examine the relationship between employee empowerment and service recovery and determine the mediating effect of empowerment on the relationship between service innovation and service recovery.

The paper is organised and arranged to cover the main ideas that help to explore the relevant literature and discover major findings, comprising of several sections and subsections. First, the study discusses the theoretical framework related to service recovery, service innovation and employee empowerment as an attempt contributed towards filling a gap in the literature on the relationship between service innovation and service recovery by investigating if there is any evidence of a direct or indirect relationship between variables. Second, the research design and methodology are discussed, followed by the presentation of the research results. The discussion, then, explores the links between the study's findings and findings in previous studies. Finally, the theoretical and practical implications of the research are discussed.

\section{THEORETICAL FRAMEWORK}

\section{1) SERVICE RECOVERY}

Service recovery in service organisations is an effective response to service failures when they do occur due to mistakes which are an unavoidable challenge in the industry. Service failures lead to a damaged relationship between service providers and their customers by reducing customers' perceived values for services (Albus \& Ro, 2017). Despite the best of intentions, policies, training and procedures that have been taken, service failures still occur in the service industry (Cranage, Sujan \& Godbey, 2005). Thus, it is difficult for organisations to eliminate all service failures and achieve zero defects in the service encounter. However, once a service failure occurs, service 
recovery is required to compensate the customer and avoid potentially short- or longlasting damage to the business. One of the main methods for recovering mistakes in service encounters is the process of service recovery - helping organisations change a customer's negative attitude towards services to a positive one when it is implemented through appropriate methods (Maxham, 2001). Thus, service recovery refers to the corrective actions that can be taken by service providers after service failures to reduce the damage to customers (Wong, Newton \& Newton, 2016).

Service recovery can be seen as a comprehensive process of identifying service failure, effectively resolving customer problems, classifying their root causes and yielding data that can be integrated with the other measures of performance to assess and improve the service system (Tax \& Brown, 1998). It is defined as the attempts by organisations to rectify customers' perceived service failure (Maxham, 2001) or the actions of the employees in solving customer problems and changing the negative attitude of dissatisfied customers and retaining customer patronage (Lewis \& McCann, 2004). The authors could say that service recovery is an organisational process of identifying service failures as perceived by customers and solving their problems using different actions that aim to improve the service system simultaneously changing the negative attitudes of dissatisfied customers. Consequently, service recovery is considered a subsystem operating under an overall organisational system; the joints and bolts of this system are the service employees themselves, the doctrine that governs it are the organisational values and policies and the hoped-for final product is a happy customer.

Most of the previous studies (Bell \& Zemke, 1987; Bitner, Booms \& Tetreault, 1990; Kelley, Hoffman \& Davis, 1993; Boshoff, 1997; Bowen \& Johnston, 1999; Sparks, 2001; Dutta, Venkatesh \& Parsa, 2007; Johnston \& Michel, 2008) confirmed that the methods of service recovery can be classified into two types, namely: 'psychological service recovery' that includes acknowledgement, apology, empathy, managerial intervention, customer input, explanation, providing assurance and owning the problem; and 'tangible service recovery' that includes compensation, free gratis, upgrade, refund, discount, coupon, free ancillary, symbol atonement (value-added atonement), correcting, replacement and urgent reinstatement.

The first method of service recovery - psychological service recovery - is defined as the attempt to rectify customers' perceived service failure by expressing concern for 
them and their problems. Thus, service failure can be solved by acknowledging that a problem had occurred, apologising, showing empathy by listening to the customer and/or providing assurance that the problem had been/will be solved and will not occur again. In the service recovery process, psychological techniques such as expressing concern by apologising and showing empathy for customer problems are critical and recommended, therefore, being one of the fundamental parts of service recovery procedures (Bell \& Zemke, 1987; Johnston \& Fern, 1999; Miller, Craighead \& Karwan, 2000). Expressing empathy for customers requires the service providers exhibiting concern about the problem, fixing the problem and diminishing customer inconvenience (Boshoff, 1999). Psychological service recovery is enough in some circumstances with the minor errors in the service failure, but customers usually expect more efforts besides an empathetic apology to rectify service failure and, therefore, if nothing is offered by the service provider, customers leave dissatisfied, believing that the apology was not sincere (Seawright et al., 2008).

The second method of service recovery is tangible service recovery that refers to the attempt to resolve service failure by completing the primary service, re-performing the service and exchanging the product or refunding the cost (Miller et al., 2000; Lewis \& McCann, 2004; Al-Sabi, 2011). The elements of tangible service recovery that include compensation of dissatisfied customers, including free gratis, coupon, refund, discount, upgrade, free ancillary and symbol atonement are supported and considered important in resolving most service failures (Lewis \& McCann, 2004). Tangible service recovery represents the commitment of the service provider to carrying out their initial obligation to customers or providing fair restitution for service failure.

\section{2) SERVICE INNOVATION}

In reviewing the literature on innovation, various definitions emerge highlighting innovation as a term used with different meanings (value creation, novelty, creativity, and economic growth) based on various settings (Wikhamn, Armbrecht \& Wikhamn, 2018). The first definition was presented by Schumpeter in 1934 (Martinez-Ros \& Orfila-Sintes, 2009, p. 633) who defined innovation as "the creation of new possibilities for additional value added, taking into account not only the typical product/process innovation of manufacturing but also market, organisational, and resource input 
innovation". Other scholars (Amabile et al., 1996; Oldham \& Cummings, 1996; Amabile, 1996, 1997; Coveney, 2008) confirmed that innovation refers to the successful implementation of the generated ideas (new and useful ideas) or products at the organisational level. Mostafa (2005: p.8) introduced a definition of innovation as a "systematic development and practical application of a new idea". Similarly, Hyland and Soosay (2008, p. 231) described it as "the introduction of new and useful products, services, methods, practices or processes that add value to the organisation". A comprehensive definition for innovation is presented by Oslo Manual $(2005$, p.46) as "the implementation of a new or significantly improved product (good or service) or process, a new marketing method or a new organizational method in business practices, workplace organization or external relations". Innovation implies idea transformation into new services/products (Rank, Pace \& Frese 2004; Flaatin, 2007). It is composed of idea generation and idea implementation (Al-Ababneh, 2014).

Innovation can be classified into two types based on the level required with regard to changes. They are:

1. Incremental, continuous or minor innovation.

Incremental innovation refers to small changes in products, procedures or services of an organisation. It is new to the organisation but reflects a simple adjustment of existing practices and requires simple changes in organisational structures or processes for its implementation (Oldham \& Cummings, 1996). Incremental innovation refers to implementing small and cumulative changes (Martínez-Pérez et al., 2016) that improve existing services/products, methods and processes (Martinez-Ros \& Orfila-Sintes, 2009; Souto, 2015). It is characterised by the low degree of novelty, less potential for positive impact on performance and less cost and risk (Martinez-Ros \& Orfila-Sintes, 2009; Souto, 2015).

2. Radical, discontinuous or major innovation.

In contrast, radical innovation refers to new larger changes to the industry and organisation in organisational products, services or procedures, organisation's processes and output (Ettlie, Bridges \& O'keefe, 1984). Radical innovation reflects broader shifts in perspective and reorientation of existing practices and requires major changes in organisational structures or processes for its implementation (Oldham \& Cummings, 1996). The process of innovation occurs 
cumulatively until it is interrupted by major developments. The key developments in discontinuous innovation significantly enhance the price or performance compared to available value offerings, resulting in the disability of older propositions to compete through design, greater efficiency or economies of scale (Tushman \& Anderson, 1986). Radical innovation is interpreted as a profound, risky and costly change to achieve significant performance improvement (Martínez-Pérez et al., 2016).

Innovation can take two basic forms: product innovation that refers to the changes in the products or services and process innovation that refers to the changes in the production and delivery to offer products/services. The degree of innovation, however, takes two major forms: minor changes or incremental innovation and major changes or radical innovation (Tidd, 2001). Furthermore, innovation can be classified into four categories (Wikhamn, Armbrecht \& Wikhamn, 2018); these are:

1. Process innovation: it encompasses substantial changes in equipment, techniques and/or software by implementing an improved or new delivery approach.

2. Product innovation: it introduces an improved or new good/service in terms of its intended uses and characteristics.

3. Organisational innovation: it offers new business practices or workplace organisation, external relations by implementing a new work organisation method.

4. Marketing innovation: it involves alterations in the product/service design, promotion, placement or pricing by introducing a new marketing method.

Historically, the innovation theory was developed in the manufacturing industry (Gallouj \& Weinstein, 1997). Although the features of innovation and production in services are different from manufacturing (Evangelista \& Sirilli, 1995), organisational factors, the close interaction between production and consumption, the large role of human resources in service production and the intangible nature of services play a critical role in producing and delivering new services (Gallouj \& Weinstein, 1997; Gallouj, 2002). The present differences between manufacturing and services create difficulties in distinguishing between process and product innovation, but there are several arguments confirming that innovation can be implemented in services such as manufacturing which indicate that the service sector is an innovative one and, 
therefore, the applications of innovation in manufacturing have begun to permeate the service sector.

Innovation in services is less radical than in manufacturing (Barras, 1986), the emphasis is on the process rather than the product (Gallouj, 2002) and technological applications (Gallouj, 2002; Mattsson, Sundbo \& Fussing-Jensen, 2005; Tether, 2005). Innovation is more easily copied and rapidly implemented in services compared to manufacturing (Voss et al., 1992). The concept of service innovation has been debated with some scholars propounding that product innovation and service innovation are different in their own theories (Edvardsson \& Olsson, 1996), others assumed that innovation theories fit within the service context (Nijssen et al., 2006). The third view suggested that service innovation brings forward the neglected elements of innovation that are relevant for services as well as for manufacturing (Coombs \& Miles, 2000, Gallouj \& Savona, 2009; Lusch \& Nambisan, 2015). As a result, product innovation theories are often suggested to cover service innovation (Chen, Tsou \& Huang, 2009), thus, service innovation can be seen as a special case of innovation (Möller, Rajala \& Westerlund, 2008).

Service innovation is defined as "new or novel ideas which focus on services that provide new ways of delivering a benefit, new service concepts or new service business models through continuous operational improvement, technology, investment in employee performance or management of the customer experience" (Verma et al., 2008, p. 7). Service innovation includes changes in the service characteristics that are the competencies of providers and customers, technical characteristics of the material and immaterial aspects and characteristics of customers' value or services (Gallouj \& Weinstein, 1997); thus, it is a change in the manufacturing firm and customer competencies (Gustafsson, Kristensson \& Witell, 2012) and a new change in practice that offers value to the service provider and its customers rather than others (Toivonen \& Tuominen, 2009; Salunke, Weerawardena \& McCollKennedy, 2011). Service innovation is an effective way for refining existing services, developing new services and improving service quality (Cheng, Chen \& Tsou, 2012). It is a competitive advantage that enables service organisations to achieve high levels of performance (Matear et al., 2004) and a technological development that influences the design of service-based business models in the hospitality industry (Souto, 2015). 
This study focuses on process innovation and product innovation and, therefore, it is necessary to distinguish between the two. Prajogo and Sohal (2006) suggested that process innovation is a change in the production of the service/product offered by the organisation, while product innovation refers to generating ideas or creating something new that is reflected in changes in the service/product. Orfila-Sintes and Mattsson (2009) suggested another distinction, referring to process innovation as new production technology and methods of delivering products and of supplying services, while product innovation is a new or improved good/service with respect to its fundamental characteristics, immaterial components, incorporated software, technical specifications, user-friendliness and intended uses. Based on the previous distinctions, one can conclude that process innovation leads to product innovation in the end supporting the importance of both types of innovation and their outcomes regarding the level of output, product (good/service) quality or production costs.

The hospitality industry faced many challenges, forcing hospitality organisations to update and modify services to meet the change in their customer needs and wants (Ottenbacher, 2007). With the increasing competitiveness of the market regarding the quality and distinction of services and products, hotels are required to become more innovative in service, procedures and processes by developing delivery services to customers (Al-Ababneh, 2014). Innovation becomes an important technique in the development process for successful hospitality organisations by developing and upgrading operations, offering new services, modifying existing services and adding value to customers (Ottenbacher \& Gnoth, 2005; Victorino et al., 2005; Wong \& Ladkin, 2008). Innovation in the hospitality industry can achieve many benefits such as competitive advantage, continuous improvement and improved customer services (Wong \& Pang, 2003b; Ottenbacher \& Gnoth, 2005). Furthermore, Orfila-Sintes, Crespi-Cladera and Martínez-Ros (2005) found that hotels with high innovation have the capacity to differentiate their services and products. Innovation in the hotel industry means the implementation of new ideas in the product/service and processes (Wikhamn, Armbrecht \& Wikhamn, 2018). Innovation in hospitality includes communication technologies, control processes, IT equipment, safety, gastronomic services, cleaning, laundry and room service (Martinez-Ros \& Orfila-Sintes, 2012). Most studies in innovation in the hotel industry discuss the role of new technologies (Orfila-Sintes \& Mattsson, 2009; Martinez-Ros \& Orfila-Sintes, 2009; Miralles, 2010; 
Campo, Díaz \& Yagüe, 2014; Sarmah, Kamboj \& Rahman, 2017). This means hotels use innovation by differentiating them, increasing efficiency and competitive advantage and introducing new technological solutions for improving their services (Orfila-Sintes \& Mattsson, 2009; Martinez-Ros \& Orfila-Sintes, 2012; Nieves \& Segarra-Ciprés, 2015).

\section{3) EMPLOYEE EMPOWERMENT}

The early use of empowerment refers to power and control (Kanter, 1983). Empowerment can be effective in improving productivity and performance when it is applied properly (Sashkin, 1984). It refers to a set of procedures that may empower employees (Conger \& Kanungo, 1988) with less direct supervision (Randolph, 1995). Empowerment can be defined as a set of practices that involve increased employee autonomy, the delegation of authority, information sharing and increased reliance on teams (Randolph, 2000, Hon \& Chan, 2012). Employee discretion over certain tasks is the core element of empowerment that grants employees more responsibilities without neglecting them (Bowen \& Lawler, 1992).

There are two main types of empowerment, namely psychological empowerment and structural empowerment (Eylon \& Bamberger, 2000; Greasley et al., 2008). The first, psychological empowerment, refers to a motivational concept of self-efficacy (Conger \& Kanungo, 1988). Lee and Koh (2001, p. 686) suggested the following inclusive definition for psychological empowerment" "the psychological state of a subordinate perceiving four dimensions of meaningfulness, competence, selfdetermination and impact, which is affected by the empowering behaviours of the supervisor". It consists of four dimensions, each necessary for the complete empowerment of an employee. If one or more dimension is missing, the overall feeling of empowerment will reduce (Thomas \& Velthouse, 1990). Spreitzer (1995) developed the dimensions of psychological empowerment, namely impact, competence, meaning and self-determination. The second type, structural empowerment, can be seen as a management technique that involves the delegation and sharing of power and control between managers and their subordinates (Kanter, 1983). It is an organisational practice that transfers power through access to information, resources, skills development, responsibility, support and knowledge (Eylon \& Bamberger, 2000). 
Hospitality organisations achieve successful service and customer satisfaction by empowering employees with the necessary autonomy and discretion through improving operations and increasing profit (Lashley, 1995). Empowerment also provides employees with different benefits and experiences (Lashley, 2001); thus, empowered employees are more committed to improving service quality in hospitality organisations (Lashley, 1995). Empowerment can prepare employees to deal with and correct job-related issues without referring to senior-level management (Klidas, 2001).

\section{4) SERVICE INNOVATION, SERVICE RECOVERY AND EMPLOYEE EMPOWERMENT}

Most previous studies focused on service innovation and its impact on service quality and delivery and no attention has been paid to studying the impact of service innovation on service recovery. For example, Wise and Baumgartner (1999) also suggested service innovation as the most useful technique to seize business opportunities for business firms. Van Der Aa and Elfring (2002) suggested that service innovation generates opportunities towards enhancing the efficiency of the delivery process and also increases the quality in addition to supporting the introduction of new service concepts. Cheung (2006) found that the implementation of service innovation improved service quality in hotels, both displaying a significant positive relationship. Claver-Cortes et al. (2008) confirmed the positive impacts of service innovation on performance, indicating that hotels with high service innovation had higher levels of performance. Service innovation is directly or indirectly associated with providing value to both the customer and the service provider (Salunke et al., 2011). Similarly, Irfan and Kee (2013) suggested that service quality in organisations can be improved by service innovation. As a result, service innovation reduces the incidents of service failures, followed by service recovery.

Bin Shahriar, Islam and Khan (2018) tried to investigate organisational efforts to overcome the risk of losing customers and satisfying them through service innovation even in the presence of service failure. This time, the study objective was to have a deeper understanding of customer attitudes towards a well-designed service innovation along with inadequately premeditated service recovery policies after the service failure at a restaurant service environment. For comprehensive understanding, 
the paper argues about the common service failure, recovery actions and innovation efforts of a particular restaurant business from both perspectives, i.e., customer insight as well as the provider's perspective. Researchers also tried to find out the mismatch of perceptions by cross-checking the valid information. In this case, the restaurant, 'Chittagong Express', experienced the same thing. Their innovation helped them immensely to create a brand image in the customers' minds, but it has a huge chance of losing their trust due to repeated service failure.

Despite the absence of empirical studies in the relationship between service innovation and service recovery, a few studies were conducted. For example, Heijden et al. (2013) conducted a study aimed at exploring the role of innovation in improving service recovery performance and quality through developing ideas. They found that innovation through idea improvement had a significant positive effect on the speed and quality recovery. Innovation may both impair and benefit recovery performance, which provides improvement ideas by sourcing knowledge from customers. These improvement ideas, in turn, improved product solutions and service procedures, ultimately enhancing the speed and quality of recovery. Barras (1986) suggested that service innovation providing new technology improved the efficiency of existing service delivery process, service and product quality. Service innovation enhances service quality by developing services and refining the existing services (Berry et al., 2006; Cheng et al., 2012; Gremyr et al., 2014; Seesaiprai, 2016). In light of the preceding discussion and findings, the study proposed the following hypothesis:

\section{H1: Service innovation has a positive and significant effect on service recovery.}

Implementing service innovation successfully in service organisations requires empowered employees to enact, protect and realise the innovation needed to deliver high quality services (Rafiq \& Ahmed, 1998). Performance can be enhanced by managers empowering their employees and involving them in decision-making processes (Rafiq \& Ahmed, 1998; Martin \& Bush, 2006). Empowerment enhances employees' professional growth and skills, enabling them to set higher performance goals and to respond to customer needs. Therefore, empowerment moderates employee actions that influence the relationship between service innovation and service quality in organisations (Rafiq \& Ahmed, 1998; Luria, Gal \& Yagil, 2009) and improving employees' customer service performance by engaging in service innovation (Gómez \& Rosen, 2001). Consequently, employee empowerment has a 
critical role in the delivery of service quality and service innovation by providing them with significant decision-making authority that allows them to initiate customised solutions (Conger \& Kanungo, 1988; Gómez \& Rosen, 2001; Sok \& O'Cass, 2015). Amabile (1988) indicated that employees will be more creative when they have autonomy and impact, thus, empowerment equips employees with the ability to deliver and create quality services (Sok \& O'Cass, 2015).

Many scholars argued that psychological empowerment's dimensions impacted innovative behaviour positively. For instance, Bass (1985) suggested that employees' work meaning, impact and self-determination are positively contributed to employees' innovative behaviour. Another dimension of psychological empowerment - selfefficacy (competence) - is also positively related to innovative behaviour (Amabile, 1988; Redmond, Mumford \& Teach, 1993). Spreitzer (1995) found a positive relationship between psychological empowerment and innovation performance empowerment can be used for maintaining the support of innovation by encouraging the participation of employees in innovation activities. Howard and Foster (1999) confirmed that service innovation can develop empowerment. Bolat (2008) demonstrates that employee empowerment leads to an increase in the demand and efforts to create innovation. Empowered employees become the source of new ideas and innovation (Kahreh, Ahmadi \& Hashemi, 2011). Bhatnagar (2012) displayed that empowerment causes higher levels of innovation performance; in other words, when employees feel empowered in their work, they seek out new ideas for introducing new services/products.

Employee empowerment has a strong relationship with innovation, which encompasses both actual innovative behaviour and the encouragement to be innovative. It is important for initiating the innovation process as it provides them with independence and creativity that help employees provide new and creative procedures and processes (Fernandez \& Moldogaziev, 2013). Empowering employees is vital within the firm (Rosado, 2006) to achieve a collaboration that can lead to innovations (Kennedy \& Schleifer, 2006). An empowerment strategy is crucial to increase innovation (Bektas \& Sohrabifard, 2013; Elkhwesky, Salem \& Barakat, 2019). Empowered employees improve performance by providing innovative ways of correcting errors in service delivery and redesigning work processes (Fernandez \& Moldogaziev, 2013); empowerment fosters innovative behaviour increasing job 
productivity (Chang \& Liu, 2008) and innovation performance in the hotel industry (Masadeh, Al-Sabi \& Al-Ababneh, 2019). Therefore, in light of the earlier arguments, the following hypothesis is put forward:

\section{H2: Service innovation has a positive and significant effect on empowerment.}

Empowerment is a way that enables employees to reduce service failure (Tehrani, 1995), it plays an important role in service recovery by identifying and solving customer problems through certain methods (Hart, Heskett \& Sasser, 1990). When employees were fully empowered, fewer service failures were perceived by customers (Sparks, Bradley \& Callan, 1997). Thus, empowered employees would be more likely to adopt active and tangible service recovery methods when faced with service failures (Lin, 2009) by responding to customer needs more quickly during service recovery and displaying more warmth and enthusiasm in their interactions with customers (Bowen \& Lawler, 1992). Employees who have the power to deliver greater service quality are able to recover and prevent service failures by responding to customer needs and requests (Cranage, 2004). Service providers who recognised a high level of empowerment tended to be more effective in service failure recovery (Carson et al., 1998). Empowered service providers have the flexibility and necessary resources to satisfy customer needs, and they are obliged to ensure a higher quality of service (Randolph, 1995; Spreitzer, 1996; Kashyap, 2001). Thus, implementing service recovery requires employee empowerment to respond to service failure (Duffy, Miller \& Bexley, 2006), as service recovery is a process related procedure (Grönroos, 1988).

Many studies have been conducted on the relationship between empowerment and service recovery. Some studies (e.g., Babakus et al., 2003; Yavas et al., 2003) reported a strong positive relationship between empowerment and service recovery. Other studies (e.g., Conger \& Kanungo, 1988; Hart et al., 1990; Bowen \& Lawler, 1992, 1995; Carson et al., 1998; Enz \& Siguaw, 2000) revealed that empowerment has an effective role in service recovery; these findings confirmed that empowerment works as an effective strategy in supporting service recovery. This strategy can contribute towards the speedy solving of customer problems (Magnini \& Ford, 2004). Recently, some studies conducted in the hotel industry (i.e., Yavas, Karatepe \& Babakus, 2010; Crawford \& Riscinto-Kozub, 2010; Schumacher \& Komppula, 2016, Al-Ababneh et al., 2018) found that empowerment has a positive relationship with service recovery. Therefore, the following hypothesis is advanced: 
H3: Employee empowerment has a positive and significant effect on service recovery.

To the best of the authors' knowledge, no study was conducted to investigate the mediating effect of employee empowerment on the relationship between service innovation and service recovery. Thus, this study is considered the first one to explore the role of employee empowerment as a mediator between service innovation and service recovery. In light of the preceding discussion and findings that argued service innovation had a strong and positive relationship with empowerment from one side and, on the other hand, empowerment had the same with service recovery, this study hypothesises that:

\section{H4: Employee empowerment mediates the relationship between service} innovation and service recovery.

Figure 1 illustrates the theoretical framework for this study. The independent variable was service innovation, employee empowerment as the mediator variable, while the dependent variable was service recovery.

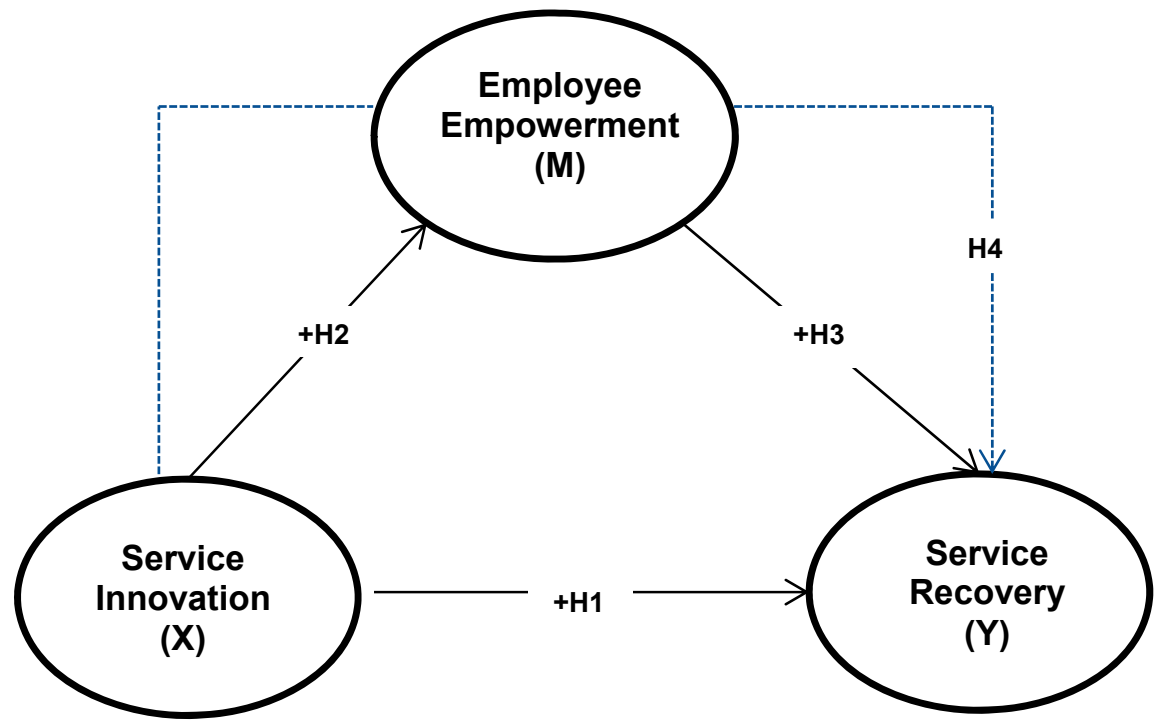

Note(s): The mediation model. M: Mediator; $\mathrm{X}$ : Independent variable; $\mathrm{Y}$ : Dependent variable. Figure 1: The Conceptual Research Model Source: Author's own elaboration

\section{RESEARCH METHODOLOGY}

\section{1) SAMPLING PROCEDURE}


The study was conducted in five-star hotels in Jordan. Four hundred and fifty questionnaires were randomly distributed among employees working in 14 five-star hotels during the summer of 2019; the number distributed differed based on how many each hotel could take. Consequently, of the 393 returned questionnaires, 12 were not valid due to incompleteness. Thus, 381 valid questionnaires were utilised for data analysis with a response rate of $84.6 \%$. The data were analysed using an SPSS program through statistical tests such as Exploratory Factor Analysis (EFA), descriptive analysis and linear regression analysis, with multiple regression analysis using "Hayes PROCESS macro" to empirically examine the model. Furthermore, the Partial Least Squares Structural Equation Modelling (PLS-SEM) method was employed to test the construct validity by using Confirmatory Factor Analysis (CFA).

\section{2) MEASURES}

A quantitative survey method was applied using a 60-item questionnaire to measure the study's variables from employees' perceptions. The questionnaire consisted of four parts. The first part, the service innovation scale, included two dimensions - product innovation (5 items) and process innovation (4 items), adapted from Prajogo and Sohal's (2003) scale. The second part, the employee empowerment scale, included two dimensions - psychological empowerment (12 items) selected from Spreitzer's (1995) scale and structural empowerment (14 items) selected from Hayes' (1994) scale. The third part, the service recovery scale, included two dimensions as well tangible service recovery (5 items) selected from Boshoff and Allen's (2000) scale and psychological service recovery (20 items) from Al-Sabi's (2011) scale. The fourth part, respondents' demographic, included age, gender, education, working department and work experience. The study used a five-point Likert-type scale ranging from one being 'strongly disagree' to five being 'strongly agree' to measure service innovation, empowerment and service recovery.

\section{RESEARCH RESULTS}

\section{1) DEMOGRAPHIC RESULTS}


The profile of respondents as shown in Table 1 reveals that the hotel industry in Jordan is male-dominated, with 71 females (19\%) and 310 males (81\%). The majority of the respondents (66\%) were $26-45$ years of age. In terms of the educational level of the respondents, $58 \%$ had a secondary school education or less, $39 \%$ had undergraduate degrees and only $3 \%$ had postgraduate degrees. The majority of respondents $(68 \%)$ had 2-7 years of experience, $26 \%$ had more than eight years of experience and $6 \%$ had less than one year of experience. In terms of departments of the respondents, $64 \%$ were working in the front departments and $36 \%$ in the back departments.

\begin{tabular}{|c|c|c|c|c|c|}
\hline Variables & $\mathbf{N}$ & Percentage & Variables & $\mathbf{N}$ & Percentage \\
\hline Gender: & & & Age: & & \\
\hline Male & 310 & $81 \%$ & 25 or under & 95 & $25 \%$ \\
\hline Female & 71 & $19 \%$ & $26-35$ & 135 & $35 \%$ \\
\hline & & & $36-45$ & 120 & $31 \%$ \\
\hline Education: & & & $46-55$ & 21 & $6 \%$ \\
\hline Secondary school or less & 221 & $58 \%$ & 56 and more & 10 & $3 \%$ \\
\hline Undergraduate & 148 & $39 \%$ & & & \\
\hline Postgraduate & 12 & $3 \%$ & Experience: & & \\
\hline & & & Less than one year & 22 & $6 \%$ \\
\hline Working department: & & & $2-4$ years & 122 & $32 \%$ \\
\hline Front Departments & 244 & $64 \%$ & $5-7$ years & 137 & $36 \%$ \\
\hline Back Departments & 137 & $36 \%$ & 8 years and more & 100 & $26 \%$ \\
\hline
\end{tabular}

\section{2) VALIDITY AND RELIABILITY OF THE STUDY'S SCALES}

Although all the study's scales were efficient as confirmed in many previous studies, it was important to purify these scales and examine their validity and reliability. An EFA was used to confirm the construct validity and show the significant factor loadings for this study, while Cronbach's alpha ( $\alpha$ ) was used to assess the construct reliability. The following tables present the final outcomes of the factor analysis after the Varimax rotation.

As shown in Table 2, the factor analysis presented a one-dimensional structure for service innovation. The dimension is named 'service innovation' with item loadings ranging from $0.848-0.909$. The extracted dimension is, however, not consistent with previous studies (Prajogo \& Sohal, 2003; Al-Ababneh, 2014). The reason being that many studies still provided various sets of service innovation and each researcher emphasises a selection of factors based on their judgments and experience in working with various organisations. 


\begin{tabular}{|c|c|c|}
\hline \multicolumn{3}{|c|}{ Varimax Rotation - Factor Loading } \\
\hline $\begin{array}{l}\text { Factor: service innovation } \\
\text { Items }\end{array}$ & Service Innovation & Communality \\
\hline SI1 & .853 & .727 \\
\hline $\mathrm{SI} 2$ & .902 & .813 \\
\hline $\mathrm{SI} 3$ & .909 & .826 \\
\hline SI4 & .852 & .725 \\
\hline SI5 & .885 & .754 \\
\hline SI6 & .900 & .810 \\
\hline $\mathrm{SI}$ & .876 & .768 \\
\hline SI8 & .891 & .795 \\
\hline SI9 & .848 & .720 \\
\hline Eigen-value & 6.967 & \\
\hline Percentage of variance explained & $77.415 \%$ & \\
\hline Cumulative (total explained) & $77.415 \%$ & \\
\hline
\end{tabular}

Table 2: Output of Factor Analysis for Service Innovation

Source: Author's own elaboration

As shown in Table 3, the factor analysis found out that service recovery has a dualdimensional structure with an Eigenvalue exceeding 1, the psychological service recovery with item loadings ranged from 0.52-0.89 and tangible service recovery with item loadings from $0.769-0.873$. This result is consistent with previous studies which considered service recovery a dual-dimensional variable (Miller et al. 2000; Al-Sabi, 2011; Al-Ababneh et al., 2018).

\begin{tabular}{lccc}
\multicolumn{5}{c}{ Varimax Rotation - Factor Loading } \\
$\begin{array}{l}\text { Factor: service recovery } \\
\text { Items }\end{array}$ & $\begin{array}{c}\text { Psychological Service } \\
\text { Recovery (PSR) }\end{array}$ & $\begin{array}{c}\text { Tangible Service } \\
\text { Recovery (TSR) }\end{array}$ & Communality \\
\hline PSR1 & .849 & & .730 \\
PSR2 & .894 & & .827 \\
PSR3 & .777 & .656 \\
PSR4 & .861 & & .753 \\
PSR5 & .769 & & .613 \\
PSR6 & .795 & & .652 \\
PSR8 & .673 & & .509 \\
PSR9 & .524 & & .336 \\
PSR10 & .750 & & .692 \\
PSR11 & .681 & .839 & .604 \\
TSR1 & & .769 & .704 \\
TSR2 & & .793 & .707 \\
TSR3 & & .873 & .716 \\
TSR4 & & .008 & \\
Eigen-value & & & .800 \\
Percentage of variance explained & $\mathbf{7 . 2 9 1}$ & $\mathbf{1 4 . 3 4 0}$ & \\
Cumulative (Total explained) & $\mathbf{5 2 . 0 7 9}$ & $\mathbf{1 4 . 3 4 0}$ & $\mathbf{6 6 . 4 1 8}$ \\
\hline
\end{tabular}

Table 3: Output of Factor Analysis for Service Recovery

Source: Author's own elaboration

As shown in Table 4, the result of the factor analysis reveals a dual-dimensional structure for empowerment with an Eigenvalue exceeding 1. The two-dimensional solution, 'psychological' and 'structural', is consistent with previous studies which 
considered empowerment a dual-dimensional variable (Eylon \& Bamberger, 2000; Greasley et al., 2008; Al-Ababneh et al., 2017, 2018). Item loadings on the 'psychological' component ranged from 0.636-0.818, while item loadings on the 'structural' component ranged from 0.518-0.776.

\begin{tabular}{lccc}
\multicolumn{5}{c}{ Varimax Rotation - Factor Loading } \\
$\begin{array}{l}\text { Factor: empowerment } \\
\text { Psychological } \\
\text { Items }\end{array}$ & $\begin{array}{c}\text { Structural } \\
\text { Empowerment (PE) }\end{array}$ & $\begin{array}{c}\text { Communality } \\
\text { Empowerment (SE) }\end{array}$ \\
\hline PE1 & .818 & & .687 \\
PE2 & .774 & & .605 \\
PE3 & .771 & & .615 \\
PE4 & .692 & & .630 \\
PE5 & .687 & & .555 \\
PE6 & .685 & & .581 \\
PE7 & .658 & & .524 \\
PE8 & .636 & .776 & .531 \\
SE1 & & .752 & .639 \\
SE2 & & .705 & .606 \\
SE3 & & .682 & .510 \\
SE4 & & .646 & .595 \\
SE5 & & .590 & .539 \\
SE6 & & .545 & .378 \\
SE7 & & .527 & .452 \\
SE8 & & .518 & .275 \\
SE9 & & $\mathbf{1 . 7 4 6}$ & \\
Eigen-value & & & \\
Percentage of variance explained & $\mathbf{4 3 . 5 4 1}$ & $\mathbf{1 0 . 2 6 9}$ & $\mathbf{5 3 . 8 1 0}$ \\
Cumulative (Total explained) & $\mathbf{4 3 . 5 4 1}$ & $\mathbf{1 0 . 2 6 9}$ & \\
\hline
\end{tabular}

Table 4: Output of Factor Analysis for Empowerment

Source: Author's own elaboration

The measurement model was analysed through the relationship between latent and observed variables by using PLS-SEM through SmartPLS v.3.3.2. Table 5 shows the convergent validity and internal consistency of the variables through their Average Variance Extracted (AVE), Composite Reliability (CR) and Cronbach's alpha indicators. The results showed that the values of Cronbach's alpha $(\alpha>0.7)$ and Composite Reliability $(\mathrm{CR}>0.7)$ confirmed the internal consistency, while the Average Variance Extracted (AVE>0.5) and all the items had outer loadings values above 0.7 $(\lambda>0.7 ; p<0.001)$ indicating the convergent validity of the measurement model (Hair et al., 2017; 2019). 


\begin{tabular}{|c|c|c|c|c|c|}
\hline \multirow{10}{*}{$\begin{array}{l}\text { Latent variables } \\
\text { Service Innovation (SI) }\end{array}$} & Indicators & Loadings & AVE & $\mathbf{C R}$ & $\alpha$ \\
\hline & SI 1 & $0.890^{*}$ & 0.798 & 0.973 & 0.968 \\
\hline & SI_2 & $0.924^{*}$ & & & \\
\hline & Sl_3 & $0.909^{*}$ & & & \\
\hline & SI_4 & $0.885^{*}$ & & & \\
\hline & SI_5 & $0.897^{*}$ & & & \\
\hline & SI_6 & $0.896^{*}$ & & & \\
\hline & SI_7 & $0.890^{*}$ & & & \\
\hline & SI_8 & $0.896^{*}$ & & & \\
\hline & SI_9 & $0.850^{*}$ & & & \\
\hline \multirow{11}{*}{$\begin{array}{l}\text { Service Recovery } \\
\text { 1. Psychological Service Recovery (PSR) }\end{array}$} & & & & & \\
\hline & PSR_1 & $0.808^{*}$ & 0.676 & 0.946 & 0.931 \\
\hline & PSR_2 & $0.877^{*}$ & & & \\
\hline & PSR_3 & $0.794^{*}$ & & & \\
\hline & PSR_4 & $0.825^{*}$ & & & \\
\hline & PSR_5 & $0.754^{*}$ & & & \\
\hline & PSR_6 & $0.781^{*}$ & & & \\
\hline & PSR_8 & $0.714^{*}$ & & & \\
\hline & PSR_9 & $0.789 *$ & & & \\
\hline & PSR_10 & $0.831^{*}$ & & & \\
\hline & PSR_11 & $0.781^{*}$ & & & \\
\hline \multirow[t]{4}{*}{ 2. Tangible Service Recovery (TSR) } & TSR_1 & $0.775^{\star}$ & 0.619 & 0.884 & 0.871 \\
\hline & TSR_2 & $0.731^{*}$ & & & \\
\hline & TSR_3 & $0.703^{*}$ & & & \\
\hline & TSR 44 & $0.746^{*}$ & & & \\
\hline \multicolumn{6}{|l|}{ Empowerment } \\
\hline \multirow{8}{*}{ 1. Psychological Empowerment (PE) } & PE_1 & 0.768 & 0.657 & 0.904 & 0.892 \\
\hline & PE_2 & 0.795 & & & \\
\hline & PE_3 & 0.732 & & & \\
\hline & $\mathrm{PE}_{-}^{-} 4$ & 0.705 & & & \\
\hline & PE_5 & 0.788 & & & \\
\hline & PE_6 & 0.784 & & & \\
\hline & $\mathrm{PE}_{-}^{-} 7$ & 0.746 & & & \\
\hline & PE_8 & 0.710 & & & \\
\hline \multirow[t]{9}{*}{ 2. Structural Empowerment (SE) } & SE_1 & $0.775^{*}$ & 0.639 & 0.871 & 0.861 \\
\hline & SE_2 & $0.727^{*}$ & & & \\
\hline & SE_3 & $0.756^{*}$ & & & \\
\hline & $\mathrm{SE}_{-}^{-} 4$ & $0.783^{*}$ & & & \\
\hline & SE_5 & $0.798^{*}$ & & & \\
\hline & SE_6 & $0.765^{*}$ & & & \\
\hline & $\mathrm{SE}_{-}^{-} 7$ & $0.711^{*}$ & & & \\
\hline & SE_8 & $0.731^{*}$ & & & \\
\hline & SE_9 & $0.744^{*}$ & & & \\
\hline
\end{tabular}

Significance: * $(p<0.001)$. AVE: Average Variance Extracted. CR: Composite Reliability. $\alpha$ : Cronbach's Alpha Table 5: Measurement Model

Source: Author's own elaboration

Table 6 presented that all the square root of the average variance extracted from each latent variable was higher than its correlation with other latent variables, which confirms the discriminant validity of the measurement model through the Fornell and Larcker (1981) criteria. This was also confirmed through the heterotrait-monotrait (HTMT) criterion since all values presented below 0.9 (Hair et al., 2019). 
Fornell-Larcker Criterion

Empowerment $\mathbf{0 . 8 5 9}$

Service Innovation $\quad 0.669$

Service Recovery $\quad 0.747$

Heterotrait-Monotrait Ratio (HTMT)

Empowerment

Service Innovation

0.697

Service Recovery

0.785

Table 6: Discriminant Validity

Source: Author's own elaboration

\section{3) DESCRIPTIVE STATISTICS OF THE STUDY'S VARIABLES}

A descriptive analysis was conducted for the overall scales and its extracted dimensions.

\begin{tabular}{lccc}
\multicolumn{1}{c}{ Scale } & No. of Items & Mean & S.D \\
1.Service Innovation & $\mathbf{9}$ & $\mathbf{3 . 4 7}$ & $\mathbf{1 . 0 9 5}$ \\
2.Service Recovery & $\mathbf{1 4}$ & $\mathbf{3 . 6 7}$ & $\mathbf{0 . 7 5 7}$ \\
- Psychological Service Recovery & 10 & 3.79 & 0.826 \\
- Tangible Service Recovery & 4 & 3.37 & 0.931 \\
3.Empowerment & $\mathbf{1 7}$ & $\mathbf{3 . 5 1}$ & $\mathbf{0 . 5 5 4}$ \\
- Psychological Empowerment & 8 & 3.86 & 0.814 \\
- Structural Empowerment & 9 & 3.21 & 0.461 \\
\hline
\end{tabular}

Table 7: Output of the descriptive analysis

Source: Author's own elaboration

All the study's scales were computed by the mean scores of its sub-scales as shown

in Table 7. The one-dimensional service innovation scale was computed by summing up its nine items. The mean score for a scale is 3.47 with the standard deviation (SD) at 1.095. This means employees perceived that their hotels have implemented service innovation moderately. The two-dimensional service recovery scale was computed by summing up its 14 items, the results revealed that the mean score for overall is 3.67 with SD at 0.757 . At the dimensional level, the findings indicated that employees perceived their performing psychological service recovery with a mean of 3.79 $(S D=0.826)$ more than tangible service recovery with a mean score of 3.37 $(S D=0.931)$. This means employees perceived psychological service recovery more than tangible service recovery. Hence, employees were able to perform the process of service recovery to identify problems, resolve customer problems and change customer dissatisfaction to a state of satisfaction, retaining these customers. While the two-dimensional empowerment scale was computed by summing up its 17 items, the mean score for the overall scale is 3.51 with SD at 0.554 . This means that employees 
perceived that they are empowered at work; at the dimensional level, the findings indicated that employees perceived that they are more psychologically empowered with a mean of $3.86(S D=0.814)$ than structural empowerment with a mean score of $3.21(\mathrm{SD}=0.461)$.

\section{4) CORRELATION ANALYSIS AMONG VARIABLES}

To investigate the relationships among the study's variables, a correlation analysis was performed. Table 8 shows the correlations' output among the study's variables.

\section{Service Innovation Service Recovery Empowerment}

\begin{tabular}{|c|c|c|c|c|}
\hline Service Innovation & $\begin{array}{l}\text { Pearson Correlation } \\
\text { Sig. (2-tailed) }\end{array}$ & 1 & & \\
\hline Service Recovery & $\begin{array}{l}\text { Pearson Correlation } \\
\text { Sig. (2-tailed) }\end{array}$ & $\begin{array}{l}.445^{\star *} \\
.000\end{array}$ & 1 & \\
\hline Empowerment & $\begin{array}{l}\text { Pearson Correlation } \\
\text { Sig. (2-tailed) }\end{array}$ & $\begin{array}{l}.535^{* *} \\
.000\end{array}$ & $\begin{array}{l}.697^{\star *} \\
.000\end{array}$ & 1 \\
\hline
\end{tabular}

As shown in Table 8, medium correlations appear between service innovation and service recovery $(R=0.445)$ as well as between service innovation and empowerment $(R=0.535)$, while the correlation between empowerment and service recovery was higher $(R=0.697)$. These findings allude to the fact that service innovation was implemented effectively which, in turn, means that incidents of service failure followed by service recovery are effectively reduced. Empowerment is strongly related to service recovery and this means that empowerment is a necessary issue in recovering service failure. The previous results found out that all the relationships between the independent variable (i.e., service innovation), the dependent variable (i.e., service recovery) and the mediating variable (i.e., empowerment) had correlation coefficients which were less than 0.90 , indicating that the data were not affected by serious collinearity problem (Hair et al., 2010).

\section{5) TESTING HYPOTHESES}

In this research, service innovation worked as the independent variable, service recovery as the dependent variable and empowerment as the mediating variable. Testing hypotheses is presented as follows. 
As shown in Table 9, the findings of the regression analysis revealed that service innovation is a significant predictor of service recovery. Statistically, it can be seen from the table below that the value between service innovation and service recovery is $(\beta=0.445$ and $P$-value $<0.01)$. Finally, the overall model statistic in Table $9,\left(R^{2}=0.198\right.$, $\mathrm{P}=0.000$ ), supported the view that service innovation has a positive influence on service recovery and, therefore, service innovation leads to low levels of service recovery, implying that those employees working in hotels with service innovation implementation had fewer numbers of service recovery in their work. Hence, this result supports hypothesis $\mathrm{H} 1$.

\section{Independent Dependent}

\begin{tabular}{lccccc} 
& \multicolumn{5}{c}{ Service Recovery } \\
\hline Service Innovation & $\mathbf{R}$ & $\mathbf{t}$ & P-Value & $\mathbf{R}^{\mathbf{2}}$ & F Ratio \\
& .445 & 7.893 & .000 & .198 & 62.305 \\
\hline
\end{tabular}

Table 9: Regression model statistics dependent variable: service recovery

Source: own elaboration

As shown in Table 10, the result of the regression analysis reveals that service innovation is a significant predictor of empowerment. Statistically, it can be seen from the table below that the value between service innovation and empowerment is $(\beta=0.535$ and $P$-value $<0.01)$. Finally, the overall model statistic in Table $10,\left(R^{2}=0.287\right.$, $P=0.000$ ), supported the view that service innovation has a moderate positive influence on empowerment, indicating that employees perceived more empowerment when service innovation was implemented at the workplace. Therefore, this result supports hypothesis $\mathrm{H} 2$.

\begin{tabular}{lccccc} 
Independent & \multicolumn{5}{c}{ Dependent } \\
\hline Service Innovation & $\mathrm{R}$ & $\mathrm{t}$ & $\mathrm{P}$-Value & $\mathrm{R}^{2}$ & $\mathrm{~F}$ Ratio \\
& 0.535 & 10.060 & 0.000 & 0.287 & 101.196 \\
\hline
\end{tabular}

Table 10: Regression Model Statistics Dependent Variable: Empowerment

Source: Author's own elaboration

As shown in Table 11, the result of the regression analysis found out that empowerment is a significant predictor of service recovery. Statistically, it can be seen from the table below that empowerment is highly significant to service recovery. However, there's a strong influence between empowerment and service recovery $(\beta=0.697$ and $P$-value $<0.01)$. Finally, the overall model statistic in Table $11\left(R^{2}=0.486\right.$, $\mathrm{P}=0.000$ ) supported the view that empowerment has a strong positive influence on service recovery, which meant that employees who are full empowered had high levels 
of service recovery performance in their work. Hence, this result supports hypothesis H3.

Independent

\begin{tabular}{cccccc} 
& \multicolumn{5}{c}{ Service Recovery } \\
\hline Empowerment & $\mathrm{R}$ & $\mathrm{t}$ & $\mathrm{P}$ Value & $\mathrm{R} 2$ & $\mathrm{~F}$ Ratio \\
& .697 & 15.425 & .000 & .486 & 237.937 \\
\hline
\end{tabular}

Table11: Regression Model Statistics Dependent Variable: Service Recovery Source: Author's own elaboration

To examine the proposed mediation link, the multiple regression analysis and Hayes PROCESS macro (Model 4) were used to investigate the hypothesis that empowerment mediates the effect of service innovation on service recovery. The model was tested by bootstrapping it to the test of the indirect effect to determine if it is different from zero at the conditional effect at $95 \%$ confidence intervals (CI). The analysis is then run on 10,000 bootstrap samples to obtain the desired statistic for every one of them, with 10,000 computed indirect effects. These effects are then placed in ascending order to determine the lower and upper bounds of the $\mathrm{Cl}$ (Hayes, 2017).

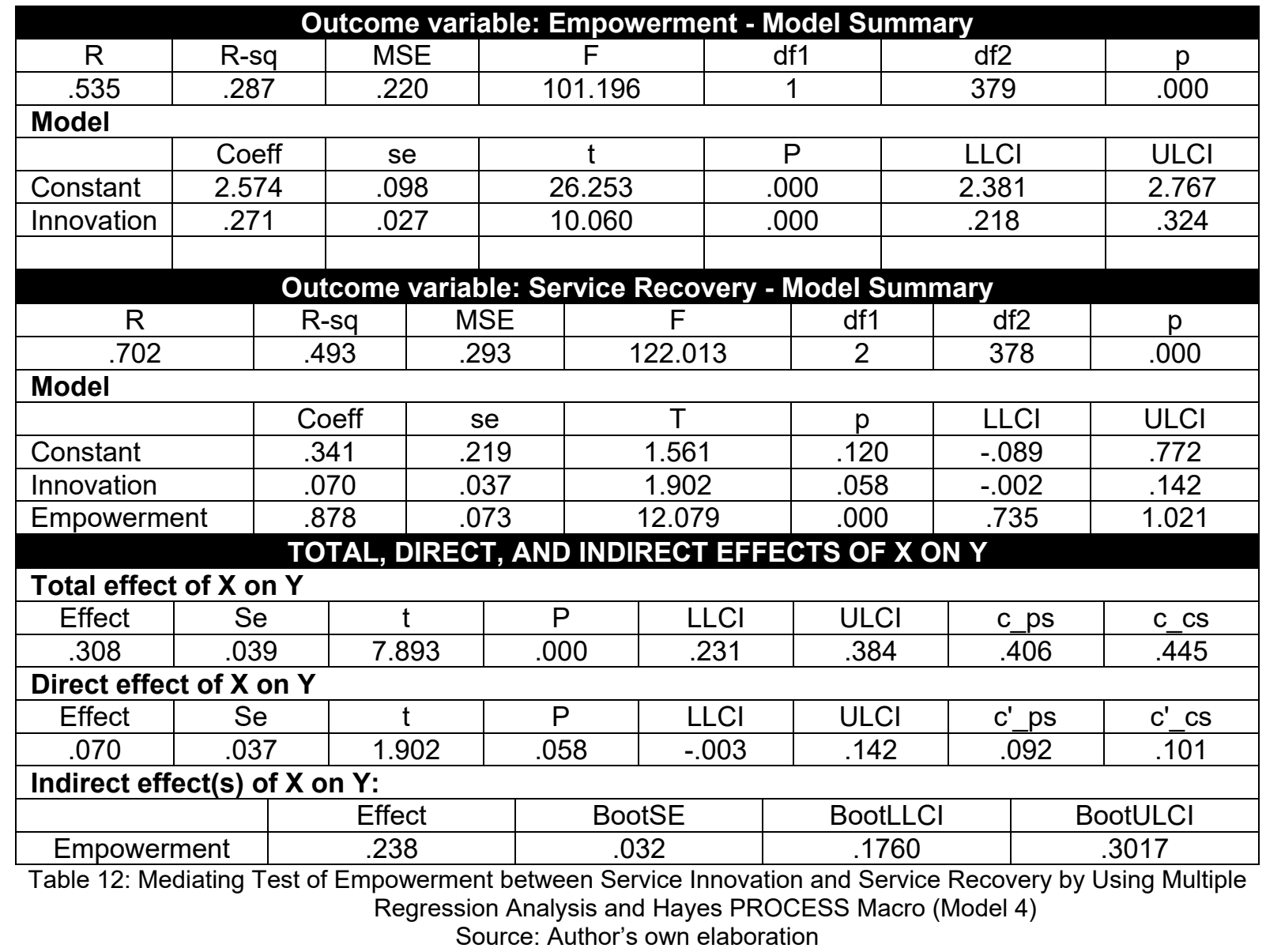


As shown in Table 12, results indicated that service innovation was a significant predictor of empowerment, $\mathrm{B}=.271, \mathrm{SE}=.027, \mathrm{p}=.000$, and that empowerment was a significant predictor of service recovery, $\mathrm{B}=.878, \mathrm{SE}=.073, \mathrm{p}=.000$. These results support the mediational hypothesis. Service innovation was no longer a significant predictor of service recovery after controlling for the mediator, empowerment, $B=.070$, $\mathrm{SE}=.037$, ns $(\mathrm{P}>.05)$, consistent with full mediation. Approximately $49.3 \%$ of the variance in service recovery was accounted for by the predictors $\left(R^{2}=.493\right)$. The indirect effect was tested using a percentile bootstrap estimation approach with 10,000 samples, implemented with the PROCESS macro Version 3 (Hayes, 2017). These results indicated the indirect coefficient was significant, $B=.238, S E=.032,95 \%$, $\mathrm{Cl}=0.1760-0.3017$. The $\mathrm{Cls}$ do not include zero and are entirely above zero, revealing that the indirect effect is positive. Service innovation was associated with service recovery scores that were approximately 0.238 points higher as mediated by empowerment.

The results of this study confirmed that empowerment does act as a full mediating variable in the relationship between service innovation and service recovery in fivestar hotels. The indirect effects of service innovation on service recovery are higher when empowerment is a full mediator in the relationship; service innovation becomes more efficient as a significant predictor of service recovery through the full mediating variable (empowerment). Hence, hypothesis H4 was fully supported and accepted. Figure 2 presents the standardised path coefficients resulting from testing the proposed model.

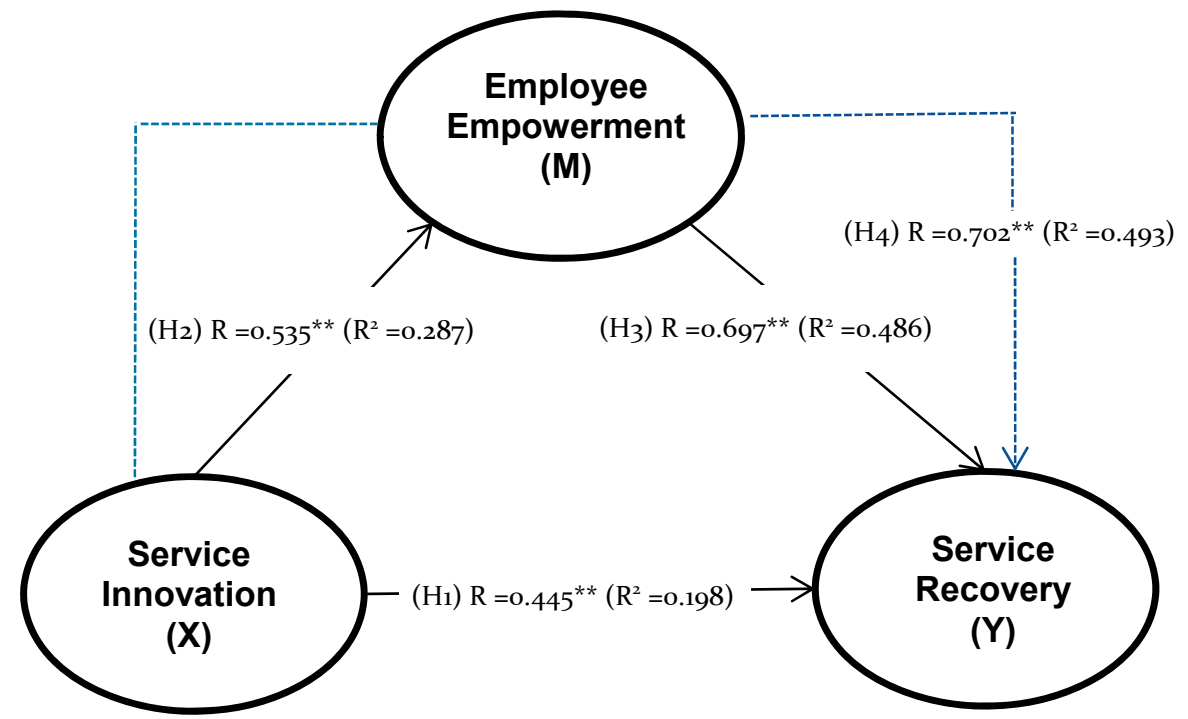

Figure 2: Hypothesised Model. Source: Author's own elaboration 


\section{DISCUSSION}

This study developed an instrument based on an extensive literature review for measuring service innovation, empowerment and service recovery performance in the hotel industry. It was empirically tested and validated using data from five-star hotels in Jordan. The service innovation instrument consisting of one scale (9 items), service recovery instrument consisting of two scales (14) and empowerment instrument consisting of two scales (17 items) are reliable and valid. This study was the first one that measured the mediating role of empowerment in the relationship between service innovation and service recovery in general, and in the hotel industry in particular. The findings provide support for the effect of empowerment as a full mediator in the relationship between service innovation and service recovery. Statistically, the results indicated that empowerment is considered a strong and full mediator in the relationship between service innovation and service recovery since the former had a weak direct effect on the latter. These results revealed that service innovation is significantly and positively correlated with empowerment and service recovery. Hence, successful service innovation implementation increases the level of empowerment and service recovery at the end. Moreover, the results depicted that empowerment has a positive effect on service recovery. In other words, empowering employees within a service innovation environment in hotels improves service recovery performance.

Furthermore, this study also revealed that service innovation improves service recovery performance indirectly through empowerment. These results supported the positive arguments that claim service innovation can create an appropriate environment for empowerment which, in turn, improves the service recovery performance at work. The explanation of the previous findings that service failure was effectively recovering by empowerment in a service innovation environment. Implementing service innovation needs to consider empowerment as a crucial aspect of service innovation implementations where increasing employee empowerment in their jobs may strongly induce positive subsequent personal outcomes (e.g., performance, trust, commitment, satisfaction, competency and positive moral values). These outcomes may motivate employees to improve service recovery performance. Also, empowerment is indeed necessary for increasing the performance of service 
recovery. Doing so will lead to increased effectiveness in service recovery performance. As a result, this study supported and accepted the four hypotheses.

It was also found that empowerment improves the level of service recovery, the results confirming the findings of previous studies. The majority of previous studies argued that empowerment had a strong positive impact on service recovery (Conger \& Kanungo 1988; Hart et al., 1990; Bowen \& Lawler, 1992, 1995; Carson et al., 1998; Hocutt \& Stone, 1998; Enz \& Siguaw, 2000; Babakus et al., 2003; Yavas et al., 2003; Al-Sabi, 2011; Al-Ababneh et al., 2018). Other studies (Bowen \& Lawler, 1992; Tehrani, 1995; Sparks et al., 1997; Carson et al., 1998; Cranage, 2004) confirmed that empowered employees are more effective in service recovery and deliver better service quality than those who are not empowered.

The current study confirmed that implementing service innovation successfully in the hotel industry requires empowered employees to deliver high levels of service quality and service recovery. These findings were consistent with previous studies (i.e. Bass, 1985; Conger \& Kanungo, 1988; Amabile, 1988; Redmond, Mumford \& Teach, 1993; Spreitzer, 1995; Rafiq \& Ahmed, 1998; Gómez \& Rosen, 2001; Rosado, 2006; Kennedy \& Schleifer, 2006; Martin \& Bush, 2006; Chang \& Liu, 2008; Bolat, 2008; Luria, Gal \& Yagil, 2009; Kahreh, Ahmadi \& Hashemi, 2011; Bhatnagar, 2012; Fernandez \& Moldogaziev, 2013; Bektas \& Sohrabifard, 2013; Sok \& O'Cass, 2015; Elkhwesky, Salem \& Barakat, 2019; Masadeh, Al-Sabi \& Al-Ababneh, 2019). Furthermore, this study is the first that confirmed employee empowerment works as a full mediator in the positive relationship between service innovation and service recovery.

\section{CONCLUSIONS}

In conclusion, to date, there is no study investigating the mediating role of empowerment on the relationship between service innovation and service recovery in the hotel industry. A small number of studies have focused on the relationship between service innovation and service quality rather than service recovery. The majority of the relevant literature supports the view that service innovation has a positive relationship with service quality. However, the results of this study highlight the importance of implementing service innovation in the hotel industry by revealing the positive impacts of service innovation practices on empowerment and service recovery. This study also 
confirms that empowerment acts as a full mediator in the relationship between service innovation and service recovery. These findings bridged the gaps in the literature about the mediating role of empowerment in the relationship between service innovation and service recovery. Moreover, this study confirmed the argument that a positive relationship between service innovation and service recovery is based on service innovation implementation that provides a suitable environment for service recovery through empowerment. Additionally, the current study was the first that explored the mediating role of empowerment in the relationship between service innovation and service recovery in hotels in general and in Jordanian five-star hotels in particular. Finally, the study's objectives have been achieved by finding a moderate relationship between service innovation and service recovery and a strong relationship between empowerment and service recovery. It was also found that empowerment plays the role of a full mediator in the relationship between service innovation and service recovery, confirming that empowered employees in the service innovation environment tended to be more effective in service recovery performance than those who are not empowered

\section{1) IMPLICATIONS}

This study provided theoretical contributions to the knowledge of service innovation, empowerment and service recovery in developing countries. The results indicated that the service innovation scale with one dimension, empowerment and service recovery scales with two dimensions each are valid and reliable among employees working in five-star hotels in Jordan. The study's instrument can be used directly in other studies for different populations. Managers will be able to use this instrument to evaluate the levels of service innovation practices and empowerment and identify service recovery performance in their hotels. Researchers will also be able to use it to develop the theories of service innovation, empowerment and service recovery. The positive relationships between service innovation, empowerment and service recovery could encourage practitioners to measure the impacts of service innovation on various service performance measures.

Several practical implications for practitioners in the hotel industry have been presented in this study. Managers can use the current strong evidence that the service innovation implementation could improve service recovery performance among hotels 
when they encourage empowered employees. Implementing service innovation is very important for service recovery performance, especially when employees felt they are fully empowered. Therefore, to achieve more effective impacts of service innovation on service recovery performance empowerment is required as a crucial mediator. Logically, service innovation had strong positive impacts on service quality due to it being focused on quality as the main matter, but it is the opposite in the case of service recovery performance which needs to compensate for service failures when they occur. Thus, managers need to take in their considerations that service innovation will not work well on service recovery performance without empowerment as the main mediator.

\section{2) RESEARCH LIMITATIONS AND SUGGESTIONS FOR FUTURE RESEARCH}

This study has several limitations, for example, some respondents from the same hotel might have different perspectives of service innovation, empowerment and service recovery. Further, the researchers faced a shortage in the number of studies conducted on the effect of service innovation on service recovery. A future study can be conducted on the relationships between the different types of service innovation and service recovery and the relationships between each type of service innovation and various performance measures. Moreover, future research could include the empowerment approach and its two dimensions - structural and psychological empowerment - as mediating variables between service innovation and service recovery as well as service quality. Future research can be conducted to assess the levels of service innovation implementations and service recovery from managers' perspectives to explore those implementations from their viewpoints.

\section{References}

Al-Ababneh, M. Employees' service innovation behaviour and new service development in four-and five-star hotels. International Journal of Tourism and Hospitality Reviews, Vol.1, No 1, 2014, pp. 13-22.

Al-Ababneh, M.; Al-Sabi, S.; Al-Shakhsheer, F.; Masadeh, M. The influence of employee empowerment on employee job satisfaction in five-star hotels in Jordan. International Business Research, Vol.10, No 3, 2017, pp. 133-147. 
Al-Ababneh, M.; Al-Sabi, S.; Al-Shakhsheer, F.; Habiballah, M. Mediating role of empowerment between total quality management (TQM) and service recovery performance in the hotel industry. Journal of Spatial and Organizational Dynamics, Vol.6, No 3, 2018, pp. 286-313.

Albus, H.; Ro, H. Corporate social responsibility the effect of green practices in a service recovery. Journal of Hospitality \& Tourism Research. Vol. 41, No 1, 2017, pp. 41-65.

Al-Sabi, S. The effect of empowerment on the service recovery performance of front office agents in five star hotels in Jordan (PhD Dissertation). University of Surrey, Guildford, 2011. Retrieved from http://epubs.surrey.ac.uk/id/eprint/770251 [accessed 07 January 2021].

Amabile, T.M. A model of creativity and innovation in organizations. Research in Organizational Behavior, Vol.10, 1988, pp. 123-167.

Amabile, T.M. Creativity in context. Colorado: Westview Press, 1996.

Amabile, T.M. Motivating creativity in organisation: On doing what you love and loving what you do. California Management Review, Vol. 40, No 1, 1997, pp. 39-58.

Amabile, T.M.; Conti, R.; Coon, H.; Lazenby, J.; Herron, M. Assessing the work environment for creativity. The Academy of Management Journal, Vol. 39, No 5, 1996, pp. 1154-1184.

Babakus, E.; Yavas, U.; Karatepe, O.M.; Avci. T. The effect of management commitment to service quality on employees' affective and performance outcomes. Journal of the Academy of Marketing Science, Vol. 31, No 3, 2003, pp. 272-286.

Barras R. Towards a theory of innovation in services. Research Policy, Vol. 15, No 4, 1986, pp. 161-173. 
Basadur, M.; Pringle, P.; Kirkland, D. Crossing cultures: Training effects on the divergent thinking attitudes of Spanish-speaking South American managers. Creativity Research Journal, Vol.14, No 3-4, 2002, pp. 395-408.

Bass, B.M. Leadership and performance beyond expectations. New York: Free Press, 1985.

Bektaş, C.; Sohrabifard, N. Terms of organizational psychology, personnel empowerment and team working: A case study. Procedia - Social and Behavioral Sciences, Vol. 82, 2013, pp. 886-891.

Bell, C.; Zemke, R.E. Service breakdown: The road to recovery. Management Review, Vol. 76, No 10, 1987, pp. 32-35.

Berry, L.; Shankar, V.; Parish, J.; Cadwallader, S; Dotzel, T. Creating new markets through service innovation. MIT Sloan Management Review, Vol. 47, No 2, 2006, pp. 56-63.

Bhatnagar, J. Management of innovation: Role of psychological empowerment, work engagement and turnover intention in the Indian context. International Journal of Human Resource Management, Vol. 23, No 5, 2012, pp. 928-951.

Bin Shahriar, S.H.; Islam, M.U.; Khan, M.F. Effectiveness of service innovation, where service failure is an imperative issue for a small food-service brand: Case study approach. British Journal of Marketing Studies, Vol.6, No 3, 2018, pp. 46-59.

Bitner, M.J.; Booms, B.H.; Tetreault, M.S. The service encounter: Diagnosing favorable and unfavorable incidents. The Journal of Marketing, Vol. 54, No 1, 1990, pp. 71-84.

Black, H.; Kelley, S. A storytelling perspective on online customer reviews reporting service failure and recovery. Journal of Travel \& Tourism Marketing, Vol. 26, 2009, pp. 169-179. 
Bolat, T. Dönüsümcü Liderlik, Personeli Güçlendirme ve Örgütsel Vatandaslık Davranısı Iliskisi. Baskı, Ankara: Detay Anatolia Yayıncılık, 2008.

Boshoff, C. An experimental study of service recovery options. International Journal of Service Industry Management, Vol. 8, No 2, 1997, pp.110-130.

Boshoff, C. Recovsat: An instrument to measure satisfaction with transaction-specific service recovery. Journal of Service Research, Vol. 1, No 3, 1999, pp. 236-249.

Boshoff C.; Allen J. The influence of selected antecedents on frontline staff's perceptions of service recovery performance. International Journal of Service Industry Management, Vol. 11, No 1, 2000, pp. 63-90.

Bowen, D.E.; Johnston, R. Internal service recovery: Developing a new construct. International Journal of Service Industry Management, Vol. 10, No 2, 1999, pp. 118131.

Bowen, D.E.; Lawler, E.E. The empowerment of service workers: What, why, how, and when. Sloan Management Review, Vol.33, No 3, 1992, pp. 31-39.

Bowen, D.E.; Lawler, E.E. Empowering service employees. Sloan Management Review, Vol. 36, 1995, pp. 73-84.

Campo, S.; Díaz, A.M.; Yagüe, M.J. Hotel innovation and performance in times of crisis. International Journal of Contemporary Hospitality Management, Vol. 26, No 8, 2014, pp. 1292-1311.

Carson, P.P.; Carson, K.D.; Eden, W.; Roe, C.W. Does empowerment translate into action? An examination of service recovery initiatives. Journal of Quality Management, Vol. 3, No 1, 1998, pp. 133-148. 
Casidy, R.; Shin, H. The effect of harm directions and service recovery strategies on customer forgiveness and negative word-of-mouth intentions. Journal of Retail and Consumer Service, Vol. 27, 2015, pp. 103-112.

Chang, L.-C.; Liu, C.-H. Employee empowerment, innovative behavior and job productivity of public health nurses: A cross-sectional questionnaire survey. International Journal of Nursing Studies, Vol. 45, No 10, 2008, pp.1442-1448.

Chen, J.; Tsou, H.; Huang, Y. Service delivery innovation: Antecedents and impact on firm performance. Journal of Service Research, Vol. 12, No 1, 2009, pp. 36-55.

Cheng, C.C.; Chen, J.S.; Tsou, H.T. Market-creating service innovation: Verification and its associations with new service develop and customer involvement. Journal of Services Marketing, Vol. 26, No. 6, 2012, pp. 444-457.

Cheng, B.L.; Gan, C.C.; Imrie, B.C.; Mansori, S. Service recovery, customer satisfaction and customer loyalty: Evidence from Malaysia's hotel industry. International Journal of Quality and Service Sciences, Vol. 11, No 2, 2018, pp. 187203.

Cheung, C. The impact of employees' behaviour and the implementation of total quality management on service quality: A case study in the hotel industry (PhD Dissertation). University of Strathclyde, Glasgow, 2006. Retrieved from http://oleg.lib.strath.ac.uk/R/?func=dbin-jump-full\&object id=21622 [accessed 07 January 2021].

Cho, J.; Laschinger, H.K.S.; Wong, C. Workplace empowerment, work engagement and organizational commitment of new graduate nurses. Nursing Leadership, Vol. 19, No 3, 2006, pp. 43-60.

Claver-Cortes, E.; Pereira-Moliner, J.; Tari, J.J.; Molina-Azorin, J. F. TQM, managerial factors and performance in the Spanish hotel industry. Industrial Management and Data Systems, Vol.108, No 2, 2008, pp. 228-244. 
Conger, J.A.; Kanungo, R.N. The empowerment process: Integrating theory and practice. Academy of Management Review, Vol.13, No July, 1988, pp. 471-482.

Coombs, R.; Miles, I. Innovation, measurement and services: The new problematique. In Metcalfe, J.S.; Miles, I. (Eds.). Innovation Systems in the Service Economy. New York: Springer Science, 2000, pp. 85-103.

Coveney, B. Assessing the organisational climate for creativity in a UK public library service: A case study. Library and Information Research, Vol. 32, No 102, 2008, pp. 38-56.

Cranage, D.A. Conservative choice, service failure, and customer loyalty: Testing the limits of informed choice. Journal of Hospitality and Tourism Research, Vol. 28, No 3, 2004, pp. 327-345.

Cranage, D.A.; Sujan, H.; Godbey, G. Sharing the responsibility for service failure with customers: The effects of informed choice and outcome foreseeability on customer loyalty and exit. Journal of Hospitality and Leisure Marketing, Vol.13, No 3/4, 2005, pp. 207-239.

Crawford, A.; Riscinto-Kozub, K. The role of the employee: An exploratory study in service recovery satisfaction in the luxury resort industry. Journal of Tourism Insights, Vol. 1, No 1, 2010, pp. 35-44.

Daghfous, A.; Barkhi, R. The strategic management of information technology in UAE hotels: An exploratory study of TQM, SCM, and CRM implementations. Technovation, Vol. 29, No 9, 2009, pp. 588-595.

Duffy, J.M.; Miller, J.M.; Bexley, J.B. Banking customers' varied reactions to service recovery strategies. International Journal of Bank Marketing, Vol. 24, No 2, 2006, pp.112-132. 
Dutta, K.; Venkatesh, U.; Parsa, H.G. Service failure and recovery strategies in the restaurant. International Journal of contemporary Hospitality Management, Vol. 19, No 5, 2007, pp. 351-363.

Edvardsson, B.; Olsson, J. Key concepts for new service development. Service Industries Journal, Vol. 16, No 2, 1996, pp. 140-164.

Elkhwesky, Z.; Salem, I.; Barakat, M. Diversity management in hotels: The moderating role of empowerment and capability development. Journal of Hospitality and Tourism Insights, Vol. 2, No 2, 2019, pp. 166-185.

Enz, C.; Siguaw, J. Best practices in service quality. Cornell Hotel and Restaurant Quarterly, Vol. 41, No 5, 2000, pp. 20-29.

Ettlie, J.E.; Bridges, W.P.; O'keefe, R.D. Organization strategy and structural differences for radical versus incremental innovation. Management Science, Vol. 30, No 6, 1984, pp. 682-695.

Evangelista, R.; Sirilli, G. Measuring innovation in services. Research Evaluation, Vol. 5, No 3, 1995, pp. 207-215.

Eylon, D.; Bamberger, P. Empowerment cognitions and empowerment acts: Recognise the importance of gender. Group and Organization Management, Vol. 25, No 4, 2000, pp. 354-372.

Fernandez, S.; Moldogaziev, T. Using Employee empowerment to encourage innovative behavior in the public sector, Journal of Public Administration Research and Theory, Vol. 23, 2013, pp. 155-187.

Flaatin, C. Antecedents of organizational creativity and innovation: A differentiating perspective (MSc Dissertation). University of Oslo, Oslo, 2007. Retrieved from http://urn.nb.no/URN:NBN:no-19868 [accessed 07 January 2021]. 
Fornell, C.; Larcker, D. Structural equations models with unobservable variables and measurement error: Algebra and statistics, Journal of Marketing Research, Vol.18, No 3, pp. 328-388.

Gallouj F. Innovation in services and the attendant old and new myths. Journal of Socio-Economics, Vol. 31, No 2, 2002, pp. 137-154.

Gallouj, F.; Savona, M. Innovation in services: a review of the debate and a research agenda. Journal of Evolutionary Economics, Vol. 19, No 2, 2009, p.149.

Gallouj F; Weinstein O. Innovation in services. Research Policy, Vol.26, No 4/5, 1997, pp. 537-556.

Gómez, C.; Rosen, B. The leader-member exchange as a link between managerial trust and employee empowerment. Group Organization Management, Vol. 26, No 1, 2001, pp. 53-69.

Gomezelj, D.O. A systematic review of research on innovation in hospitality and tourism. International Journal of Contemporary Hospitality Management, Vol. 28, No 3, 2016, pp. 516-558.

Greasley, K.; Bryman, A.; Dainty, A.; Price, A.; Naismith, N.; Soetanto, R. Understanding empowerment from an employee perspective: What does it mean and do they want it?. Team Performance Management, Vol. 14, No 1/2, 2008, pp. 39-55.

Gremyr, I.; Witell, L.; Löfberg, N.; Edvardsson, B.; Fundin, A. Understanding new service development and service innovation through innovation modes. Journal of Business \& Industrial Marketing, Vol. 29, No 2, 2014, pp. 123-131.

Grönroos, C., Service quality: The six criteria of good perceived service. Review of Business, Vol. 9, 1988, pp. 10-13. 
Gustafsson, A.; Kristensson, P.; Witell, L. Customer co-creation in service innovation: A matter of communication? Journal of Service Management, Vol. 23, No 3, 2012, pp. 311-327.

Hair, J.F. Jr.; Black, W.C.; Babin, B.J.; Anderson, R.E.; Tatham, R.L. Multivariate data analysis. New Jersey: Prentice-Hall, 2010.

Hair, J.F.; Hult, G.T.M.; Ringle, C.M.; Sarstedt, M. A Primer on Partial Least Squares Structural Equation Modeling (PLS-SEM). Thousand Oaks: Sage, 2017.

Hair, J.F.; Risher, J.J.; Sarstedt, M.; Ringle, C.M. When to use and how to report the results of PLS-SEM. European Business Review, Vol. 31, No 1, 2019, pp. 2-24.

Hart, C.W.L.; Heskett, J.L.; Sasser Jr., W.E. The profitable art of service recovery. Harvard Business Review, Vol. 68, No 4, 1990, pp.148-156.

Hayes, B.E. How to measure empowerment. Quality Progress, Vol. 27, No 2, 1994, pp. 41-46.

Hayes, A.F. Introduction to mediation, moderation, and conditional process analysis: A regression-based approach. New York, NY: Guilford Publications, 2017.

Herbig, P.; Jacobs, L. Creative problem-solving styles in the USA and Japan. International Marketing Review, Vol. 13, No 2, 1996, pp. 63-71.

Hocutt, M.A.; Stone, T.H. The impact of employee empowerment on the quality of a service recovery effort. Journal of quality management, Vol.3, No 1, 1998, pp. 117132.

Hon, A.H.Y.; Chan, W.W.H. Team creative performance: The roles of empowering leadership, creative-related motivation, and task interdependence. Cornell Hospitality Quarterly, Vol. 54, No 2, 2012, pp. 199-210. 
Howard, L.W.; Foster, S.T. The influence of human resource practices on empowerment and employee perceptions of management commitment to quality. Journal of Quality Management, Vol. 4, No 1, 1999, pp. 5-22.

Hsieh, Y.-H.; Yeh, S.-Y. Modeling dynamic service recovery strategies: A signaling game approach. Kybernetes, Vol. 47, No 5, 2018, pp. 888-919.

Hyland, P.; Soosay, C. Innovation, technology and knowledge management. In Samson, D.; Singh, P. (Eds.). Operations Management: An Integrated Approach. Melbourne: Cambridge University Press, 2008.

Irfan, S.M.; Kee, D.M.H. Critical success factors of TQM and its impact on increased service quality: A case from service sector of Pakistan. Middle-East Journal of Scientific Research. Vol.15, No 1, 2013, pp. 61-74.

Johnston, R.; Fern, A. Service recovery strategies for single and double deviation scenarios. The Service Industries Journal, Vol.19, No 2, 1999, pp. 69-82.

Johnston, R.; Michel, S. Three outcomes of service recovery. International Journal of Operations and Production Management, Vol. 28, No 1, 2008, pp. 79-99.

Kahreh, M.S.; Ahmadi, H.; Hashemi, A. Achieving competitive advantage through empowering employees: An empirical study. Far East Journal of Psychology and Business, Far East Research Centre, Vol. 3, No 3, 2011, pp. 26-37.

Kanter, R.M. Frontiers for strategic human resource planning and management. Human Resource Management, Vol. 22, No 1/2, 1983, pp. 9-21.

Kashyap, R. The effects of service guarantees on external and internal markets. Academy of Marketing Science Review, Vol.10, 2001, pp. 1-19.

Kelley, S.W.; Hoffman, K.D.; Davis, M.A. A typology of retail failures and recoveries. Journal of Retailing, Vol. 69, No 4, 1993, pp. 429-452. 
Kennedy, F.; Schleifer, L. Innovation: Achieving balance among empowerment, accountability and control. Advances in Interdisciplinary Studies of Work Teams. Vol.12, 2006, pp. 113-135.

Klidas, A.K. Employee empowerment in the European hotel industry: Meaning, process and cultural relativity (Thela Thesis). Tilburg University, Amsterdam, 2001. Retrieved from https://research.tilburguniversity.edu/en/publications/employeeempowerment-in-the-european-hotel-industry-meaning-proce [accessed 07 January 2021].

Lashley, C. Towards an understanding of employee empowerment in hospitality services. International Journal of Contemporary Hospitality Management, Vol.7, No 1, 1995, pp. 27-33.

Lashley, C. Empowerment HR strategies for service excellent. Elsevier Butterworth Heinemann. Jordan Hill, Oxford: Linacre House, 2001.

Lee, M.; Koh, J. Is empowerment really a new concept? The International Journal of Human Resource Management, Vol.12, No 4, 2001, pp. 684-695.

Lewis, B.R.; McCann, P. Service failure and recovery: Evidence from the hotel industry. International Journal of contemporary Hospitality Management, Vol. 16, No 1, 2004, pp. 6-17.

Lin, W.B. Service recovery model: the integrated view. The Service Industries Journal, Vol. 29, No 5, 2009, pp. 669-691.

Luria, G.; Gal, I.; Yagil, D. Employees' willingness to report service complaints. Journal of Service Research, Vol. 12, No 2, 2009, pp.156-174.

Lusch, R.F.; Nambisan, S. Service innovation: A service-dominant logic perspective. MIS Quarterly, Vol. 39, No 1, 2015, pp. 155-175. 
Magnini, V.P.; Ford, J.B. Service failure recovery in China. International Journal of Contemporary Hospitality Management, Vol.16, No 5, 2004, pp. 279-286.

Magnini, V.P.; Ford, J.B.; Markowski, E.P.; Honeycutt, E.D. Jr. The service recovery paradox: Justifiable theory or smoldering myth? Journal of Services Marketing, Vol. 21, No 3, 2007, pp. 213-225.

Martin, C.A.; Bush, A.J. Psychological climate, empowerment, leadership style, and customer-oriented selling: An analysis of the sales manager-salesperson dyad. Journal of the Academy of Marketing Science, Vol. 34, No 3, 2006, pp. 419-438.

Martínez-Pérez, Á.; García-Villaverde, P.M.; Elche, D. The mediating effect of ambidextrous knowledge strategy between social capital and innovation of cultural tourism clusters firms. International Journal of Contemporary Hospitality Management, Vol. 28, No 7, 2016, pp. 1484-1507.

Martinez-Ros, E.; Orfila-Sintes, F. Innovation activity in the hotel industry. Technovation, Vol. 29, No 9, 2009, pp. 632-641.

Martinez-Ros, E.; Orfila-Sintes, F. Training plans, manager's characteristics and innovation in the accommodation industry. International Journal of Hospitality Management, Vol. 31, No 3, 2012, pp. 686-694.

Masadeh, M.; Al-Sabi, S.; Al-Ababneh, M. Understanding the impact of empowerment on employees' innovation performance: Evidence from the Jordanian hotel industry. Journal of Tourism, Hospitality and Sports. Vol. 44, 2019, pp. 7-22.

Matear, S.; Gray, B.J.; Garrett, T. Market orientation, brand investment, new service development, market position and performance for service organisations. International Journal of Service Industry Management, Vol.15, No 3, 2004, pp. 284-301. 
Mattsson, J.; Sundbo, J.; Fussing-Jensen, C. Innovation systems in tourism: The roles of attractors and scene-takers. Industry \& Innovation, Vol. 12, No 3, 2005, pp. 357381.

Maxham III, J.G. Service recovery's influence on consumer satisfaction, positive wordof-mouth, and purchase intentions. Journal of Business Research, Vol. 54, No 1, 2001, pp.11-24.

Melián-González, S.; Bulchand-Gidumal, J.; Lopez-Valcárcel, B.G. Online customer reviews of hotels as participation increases, better evaluation is obtained. Cornell Hospitality Quarterly, Vol. 54, No 3, 2013, pp. 274-283.

Miller, J.L.; Craighead, C.W.; Karwan, K.R. Service recovery: A framework and empirical investigation. Journal of Operations Management, Vol. 18, No 4, 2000, pp. 387-400.

Miralles, P. Technological innovation, a challenge for the hotel sector. The European Journal for the Informatics Professional, Vol. 11, No 2, 2010, pp. 33-38.

Möller, K.; Rajala, R.; Westerlund, M. Service innovation myopia? A new recipe for client-provider value creation. California Management Review, Vol. 50, No 3, 2008, pp. 31-48.

Mostafa, M. Factors affecting organisational creativity and innovativeness in Egyptian business organisations: An empirical investigation. Journal of Management Development, Vol. 24, No 1, 2005, pp. 7-33.

Nieves, J.; Segarra-Ciprés, M. Management innovation in the hotel industry. Tourism Management, Vol. 46, 2015, pp. 51-58.

Nijssen, E.J.; Hillebrand, B.; Vermeulen, P.A.; Kemp, R.G. Exploring product and service innovation similarities and differences. International Journal of Research in Marketing, Vol. 23, No 3, 2006, pp. 241-251. 
OECD; Eurostat. Oslo Manual: Guidelines for Collecting and Interpreting Innovation Data. Paris: OECD Publishing, 2005.

Ogbeide, G.; Böser, S.; Harrinton, R.; Ottenbacher, M. Complaint management in G. Hewagama, et al. International Journal of Hospitality Management, Vol. 81, 2017, pp. 73-82.

Oldham, G.R.; Cummings, A. Employee creativity: Personal and contextual factors at work. The Academy of Management Journal, Vol. 39, No 3, 1996, pp. 607-634.

Orfila-Sintes, F.; Crespi-Cladera, R.; Martínez-Ros, E. Innovation activity in the hotel industry: Evidence from Balearic Islands. Tourism Management, Vol. 26, No 6, 2005 , pp. 851-865.

Orfila-Sintes, F.; Mattsson, J. Innovation behavior in the hotel industry. Omega, Vol. 37, No 2, 2009, pp. 380-394.

Ottenbacher, M. Innovation management in the hospitality industry: Different strategies for achieving success. Journal of Hospitality and Tourism Research, Vol. 31, No 4, 2007, pp. 431-454.

Ottenbacher, M.; Gnoth, J. How to develop successful hospitality innovation. Cornell Hotel and Restaurant Administration Quarterly, Vol.46, No 2, 2005, pp. 205-222.

Petzer, D.J.; Steyn, T.F.J. Customer retention: A theoretical perspective of service failure and service recovery in the hotel industry. Acta Commercii. Vol.6, No 1, 2006, pp. 162-172.

Prajogo, D.I.; Sohal, A.S. The relationship between TQM practices, quality performance, and innovation performance: An empirical examination. International Journal of Quality and Reliability Management, Vol. 20, No 8, 2003, pp. 901-918. 
Prajogo, D.I.; Sohal, A.S. The integration of TQM and technology/R\&D management in determining quality and innovation performance. Omega, Vol. 34, No 3, 2006, pp. 296-312.

Rafiq, M.; Ahmed, P.K. A customer-oriented framework for empowering service employees. Journal of Services Marketing, Vol. 12, No 5, 1998, pp. 279-396.

Randolph, W.A. Navigating the journey to empowerment. Organizational Dynamics, Vol. 23, No 4, 1995, pp. 19-32.

Randolph, W.A. Re-thinking empowerment: Why is it so hard to achieve? Organizational Dynamics, Vol. 29, No 2, 2000, pp. 94-107.

Rank, J.; Pace, V.L.; Frese, M. Three avenues for future research on creativity, innovation, and initiative. Applied Psychology: An International Review, Vol. 53, No 4, 2004, pp. 518-528.

Rao, Y.; Yang, M.N.; Yang, Y.X. Knowledge sharing, organizational learning and service innovation in tourism. Journal of Service Science and Management, Vol.11, 2018, pp. 510-526.

Redmond, M.; Mumford, M.; Teach, R. Putting creativity to work: Effects of leader behaviour on subordinate creativity. Organizational Behaviour and Human Decision Processes, Vol. 55, No 1, 1993, pp. 120-151.

Ro, H. Customer complaining behaviors after restaurant service failure: Redress seeking complaint, friendly complaint, loyalty and neglect. International Journal of Tourism Sciences, Vol. 13, No 1, 2013, pp. 27-46.

Rosado, C. What do we mean by "managing diversity"? Workforce Diversity, Vol. 3, 2006, pp.1-15. 
Sajtos, L.; Brodie, R.J.; Whittome, J. Impact of service failure: The protective layer of customer relationships. Journal of Service Research, Vol. 13, No 2, 2010, pp. 216-229.

Salunke, S.; Weerawardena, J.; McColl-Kennedy, J.R. Towards a model of dynamic capabilities in innovation-based competitive strategy: Insights from project-oriented service firms. Industrial Marketing Management, Vol. 40, No 8, 2011, pp. 1251-1263.

Sarmah, B.; Kamboj, S.; Rahman, Z. Co-creation in hotel service innovation using smart phone apps: An empirical study. International Journal of Contemporary Hospitality Management, Vol. 29, No 10, 2017, pp. 2647-2667.

Sashkin, M. Participative management is an ethical imperative. Organizational Dynamics, Vol.12, No 4, 1984, pp. 5-22.

Schumacher, S.; Komppula, R. A case study on service recovery: Frontline employees' perspectives and the role of empowerment. European Journal of Tourism, Hospitality and Recreation, Vol.7, No 2, 2016, pp.117-127.

Schumpeter, J.A. The Theory of economic development: An inquiry into profits, capital, credit, interest, and the business cycle. Cambridge, MA: Harvard University Press, 1934.

Schoefer, K.; Ennew, C. Customer evaluations of tour operators' responses to their complaints. Journal of Travel and Tourism Marketing, Vol. 17, No 1, 2004, pp. 83-92.

Seawright, K.K.; DeTienne, K.B.; Bernhisel, M.P.; Larson, C.L. An empirical examination of service recovery design. Marketing Intelligence and Planning, Vol.26, No 3, 2008, pp. 253-274.

Seesaiprai, S. The effects of service innovation and service quality on customer's loyalty in small service enterprise: A case study on car care business in Bangkok. Review of Integrative Business and Economics Research, Vol.5, No 1, 2016, pp. 296305. 
Sok, P.; O'Cass, A. Achieving service quality through service innovation exploration exploitation: The critical role of employee empowerment and slack resources. Journal of Services Marketing, Vol. 29, No 2, 2015, pp. 137-149.

Souto, J.E. Business model innovation and business concept innovation as the context of incremental innovation and radical innovation. Tourism Management, Vol. 51, 2015, pp. 142-155.

Sparks, B.A. Managing service failure through recovery. In Kanadampully, J.; Mok, C.; Sparks B.A. (Eds.). Service quality management in hospitality tourism and leisure. Binghamton, NY: The Haworth Hospitality Press, 2001, pp. 193-221.

Sparks, B.A.; Bradley, G.L.; Callan, V.J. The impact of staff empowerment and communication style on customer evaluations: The special case of service failure. Psychology and Marketing, Vol.14, No 5, 1997, pp. 475-493.

Spreitzer, G.M. Psychological empowerment in the workplace: Dimensions, measurement and validation. Academy of Management Journal, Vol. 38, No 5, 1995, pp.1442-1465.

Spreitzer, G.M. Social structural characteristics of psychological empowerment. Academy of Management Journal, Vol. 39, No 2, 1996, pp. 483-504.

Tax, S.S.; Brown, S.W. Recovering and learning from service failure. MIT Sloan Management Review, Vol. 40, No1, 1998, pp. 75-88.

Tehrani, N. Loyalty marketing, because companies live or die by repeat business. Telemarketing, Vol.41, No 5, 1995, pp. 2-6.

Tether, B. Do services innovate (differently)? Insights from the European innobarometer survey. Industry \& Innovation, Vol. 12, No 2, 2005, pp. 153-184. 
Thomas, K.W.; Velthouse, B.A. Cognitive elements of empowerment: An 'interpretive' model of intrinsic task motivation. Academy of Management Review, Vol.15, No 4, 1990, pp. 666-681.

Tidd, J. Innovation management in context: Environment, organization and performance. International journal of management reviews, Vol. 3, No 3, 2001, pp.169183.

Toivonen, M.; Tuominen, T. Emergence of innovations in services. Service Industries Journal, Vol. 29, No 7, 2009, pp. 887-902.

Tushman, M.L.; Anderson, P. Technological discontinuities and organizational environments. Administrative Science Quarterly, Vol. 31, No 3, 1986, pp. 439-465.

Van der Aa, W.; Elfring, T. Realizing innovation in services. Scandinavian Journal of Management, Vol.18, No 2, 2002, pp.155-171.

Van der Heijden, G.A.H.; Schepers, J.J.L.; Nijssen, E.J.; Ordanini, A. Don't just fix it, make it better! Using frontline service employees to improve recovery performance. Journal of the Academy of Marketing Science, Vol. 41, No 5, 2013, pp. 515-530.

Verma, R.; Anderson, C.; Dixon, M.; Thompson, G.; Victorino, L. Key elements in service innovation: Insights for the hospitality industry. Cornell Hospitality Roundtable Proceedings, Vol. 1, No 1, 2008, pp. 6-12.

Victorino, L.; Verma, R.; Plaschka, G.; Dev, C. Service innovation and customer choices in the hospitality industry. Managing Service Quality, Vol.15, No 6, 2005, pp. 555-576.

Voss, C.; Johnston, R.; Silvestro, R.; Fitzgerald, L.; Brignall, T. Measurement of innovation and design performance in services. Design Management Journal, Vol. 3, No 1, 1992, pp. 40-46. 
Wikhamn, W.; Armbrecht, J.; Wikhamn, B.R. Innovation in Swedish hotels. International Journal of Contemporary Hospitality Management, Vol. 30, No 6, 2018, pp. 2481-2498.

Wise, R.; Baumgartner, P. Go downstream: The new profit imperative in manufacturing. Harvard Business Review, September-October 1999, pp. 133-141.

Wong, S.; Pang, W.L. Motivators to creativity in the hotel industry-perspectives of managers and supervisors. Tourism Management, Vol. 24, 2003a, pp. 551-559.

Wong, C.S.; Pang, W.L. Barriers to creativity in the hotel industry- perspectives of managers and supervisors. International Journal of Contemporary Hospitality Management, Vol.15, No 1, 2003b, pp. 29-37.

Wong, S.C.; Ladkin, A. Exploring the relationship between employee creativity and jobrelated motivators in the Hong Kong hotel industry. International Journal of Hospitality Management, Vol. 27, 2008, pp. 426-437.

Wong, J.; Newton, J.D.; Newton, F.J. Powerlessness following service failure and its implications for service recovery. Marketing Letters, Vol. 27, No 1, 2016, pp. 63-75.

Yavas, U.; Karatepe, O. M.; Avci, T.; Tekinkus, M. Antecedents and outcomes of service recovery performance: An empirical study of frontline employees in Turkish banks. International Journal of Bank Marketing, Vol. 21, No 5, 2003, pp. 255-265.

Yavas, U.; Karatepe, O.M.; Babakus, E. Relative efficacy of organizational support and personality traits in predicting service recovery and job performances: A study of frontline employees in Turkey. Tourism Review, Vol. 65, No 3, 2010, pp. 70-83.

Article info: Received 26/07/2020. Accepted 08/01/2021. Refereed anonymously. 